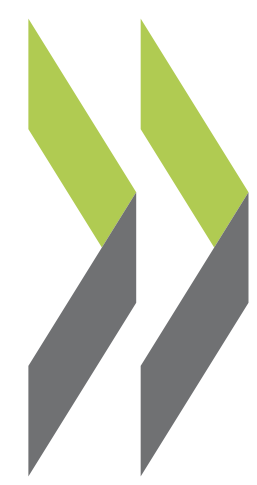

OECD Economics Department Working Papers No. 1198

Federal-State Relations

in Australia
Vassiliki

Koutsogeorgopoulou,

Annamaria Tuske 
Organisation de Coopération et de Développement Économiques

Organisation for Economic Co-operation and Development

27-Mar-2015

ECONOMICS DEPARTMENT

English - Or. English

FEDERAL-STATE RELATIONS IN AUSTRALIA

ECONOMICS DEPARTMENT WORKING PAPERS No. 1198

By Vassiliki Koutsogeorgopulou and Annamaria Tuske

OECD Working Papers should not be reported as representing the official views of the OECD or of its member countries. The opinions expressed and arguments employed are those of the author $(s)$.

Authorised for publication by Robert Ford, Deputy Director, Country Studies Branch, Economics Department.

Document available in pdf format only.

All Economics Department Working Papers are available at www.oecd.org/eco/workingpapers

JT03373286

Complete document available on OLIS in its original format

This document and any map included herein are without prejudice to the status of or sovereignty over any territory, to the delimitation of international frontiers and boundaries and to the name of any territory, city or area. 
OECD Working Papers should not be reported as representing the official views of the OECD or of its member countries. The opinions expressed and arguments employed are those of the author(s).

Working Papers describe preliminary results or research in progress by the author(s) and are published to stimulate discussion on a broad range of issues on which the OECD works.

Comments on Working Papers are welcomed, and may be sent to the Economics Department, OECD, 2 rue André-Pascal, 75775 Paris Cedex 16, France, or by e-mail to eco.contact@oecd.org.

This document and any map included herein are without prejudice to the status of or sovereignty over any territory, to the delimitation of international frontiers and boundaries and to the name of any territory, city or area.

The statistical data for Israel are supplied by and under the responsibility of the relevant Israeli authorities. The use of such data by the OECD is without prejudice to the status of the Golan Heights, East Jerusalem and Israeli settlements in the West Bank under the terms of international law.

\section{(C) OECD (2015)}

You can copy, download or print OECD content for your own use, and you can include excerpts from OECD publications, databases and multimedia products in your own documents, presentations, blogs, websites and teaching materials, provided that suitable acknowledgment of OECD as source and copyright owner is given. All requests for commercial use and translation rights should be submitted to rights@oecd.org 


\section{ABSTRACT/RÉSUMÉ}

\section{Federal-State Relations in Australia}

Australia's inter-governmental fiscal relations have gradually moved towards greater centralisation. State governments receive sizeable transfers from the federal government and own revenues only partially cover their expenses. Finding the right balance between federal control and state autonomy in public service provision and its financing has not been easy. Over time various compromises have somewhat blurred responsibilities in various functional areas or reduced incentives to raise sub-national revenues potentially affecting public sector efficiency and service quality. A better balance, one in which central government has less steerage over state activities and states have more financing autonomy but also bear increased responsibility is likely to improve outcomes. Federal-state shared responsibilities continue to affect the efficiency of healthcare service delivery in particular. A clearer delineation of roles in shared functions and possibly a reallocation of responsibilities in some cases, are important. There is also scope to reduce federal grant conditionality further to contain red tape and enhance transparency and give the states a more flexible allocation of funds. Strengthening states' revenueraising by broadening existing tax bases would promote efficiency. Consideration could be given to the introduction of a state-level income tax. The government's current review of the federal system, focusing on both spending and tax responsibilities, is welcome, as is the "whole of government" approach to the process.

This Working Paper relates to the 2014 OECD Economic Survey of Australia (www.oecd.org/eco/surveys/economic-survey-australia.htm).

JEL classification: H1, H77

Keywords: Australia, vertical, horizontal, imbalance, tax, division, responsibilities, shared, provision, services, health care, education, equalisation

\section{Les relations entre la Fédération et les États en Australie}

En Australie, les relations budgétaires entre différents niveaux d'administration ont progressivement évolué vers une plus grande centralisation. Les administrations des États perçoivent des dotations considérables du gouvernement fédéral et leurs propres recettes ne couvrent qu'une partie de leurs dépenses. Trouver le juste équilibre entre contrôle fédéral et autonomie des États pour la fourniture de services publics et leur financement n'est pas chose aisée. Divers compromis opérés au fil du temps ont quelque peu brouillé les responsabilités dans différents domaines d'intervention ou réduit les incitations des administrations infranationales à générer des recettes, ce qui peut se répercuter sur l'efficacité du secteur public et la qualité des services. Pour améliorer les résultats d'ensemble, il faudrait opérer un rééquilibrage, par lequel l'administration centrale exercerait moins de contrôle sur les activités des États et les États disposeraient d'une plus grande autonomie financière mais assumeraient davantage de responsabilités. Le partage des responsabilités entre la Fédération et les États continue de peser sur l'efficience de la prestation des services de santé, notamment. Il convient de mieux définir les rôles de chacun dans les fonctions exercées en commun et éventuellement de réattribuer les responsabilités dans certains cas. Il y a également lieu de continuer de réduire la conditionnalité des dotations fédérales afin de limiter la bureaucratie et d'améliorer la transparence, et de permettre aux États de faire un usage plus souple des fonds. Augmenter la capacité de prélèvement fiscal des États en élargissant les bases d'imposition existantes irait également dans le sens d'une plus grande efficience. Il conviendrait d'envisager d'introduire un impôt sur le revenu au niveau des États. Le réexamen actuel par le gouvernement du système fédéral, qui porte à la fois sur les responsabilités en matière de dépenses et de prélèvements, est une initiative bienvenue, tout comme l'approche à l'échelle de l'ensemble de l'administration suivie pour ce processus.

Ce Document de travail se rapporte à l'Étude économique de l'OCDE de l'Australie, 2014 (www.oecd.org/fr/eco/etudes/etude-economique-australie.htm).

Classification JEL : H1, H77

Mots clefs : Australie, vertical, horizontal, déséquilibre, impôts, division, responsabilités, partagé, prestation, services, soins de santé, éducation, péréquation 


\section{TABLE OF CONTENTS}

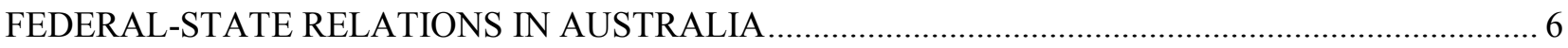

Australian inter-governmental fiscal relations: Main features and trends................................................. 6

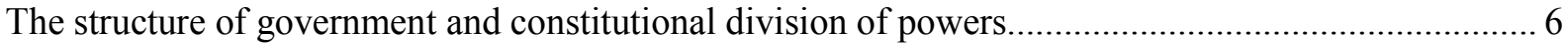

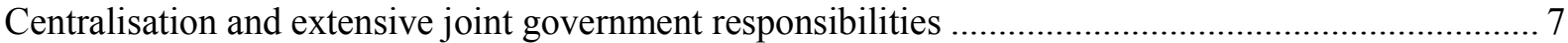

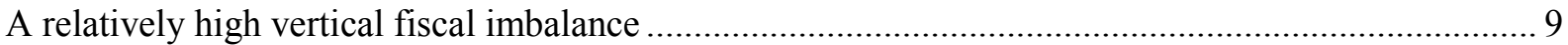

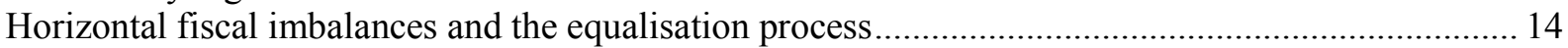

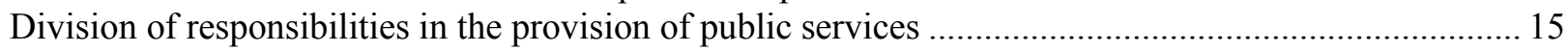

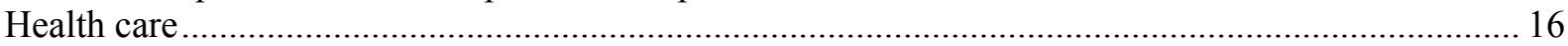

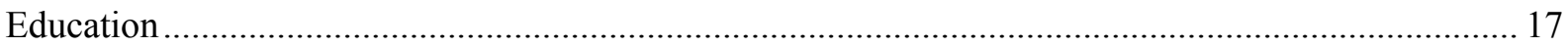

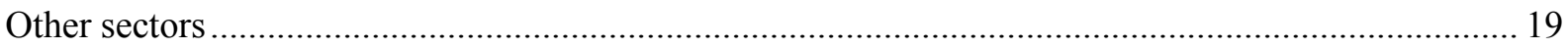

Potential reform options for better allocation of roles and responsibilities .......................................... 20

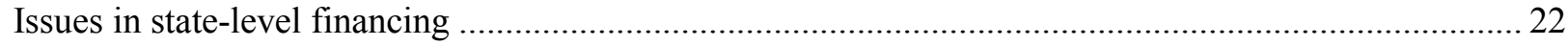

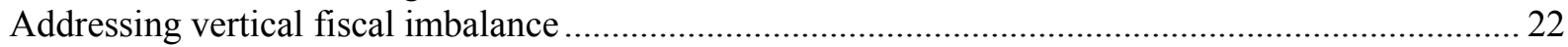

There is scope to reduce further the strings attached to federal grants .................................................22

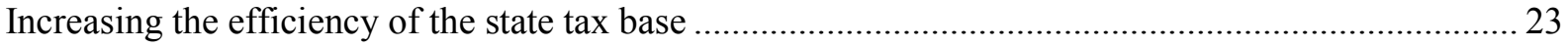

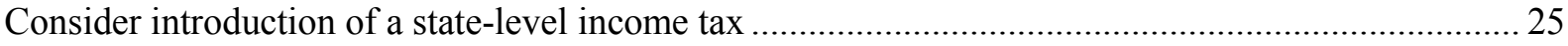

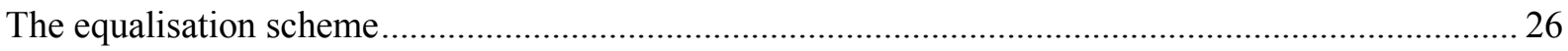

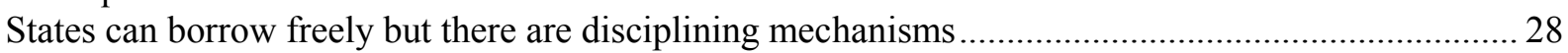

There is scope to further improve performance reporting ................................................................... 29

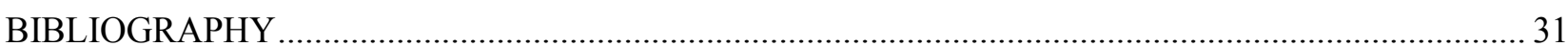

\section{Tables}

1. Commonwealth-state responsibilities for healthcare and education and training ............................ 18

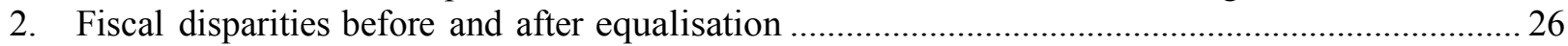

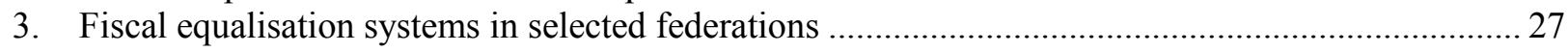

\section{Figures}

1. Decomposition of government expenditure by function.......................................................... 8

2. Expenses by government level in health and education in selected federations .............................. 9

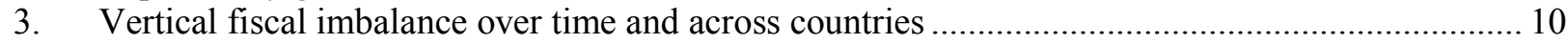

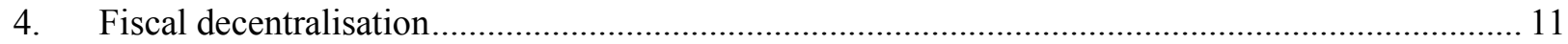

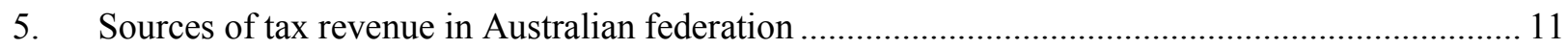

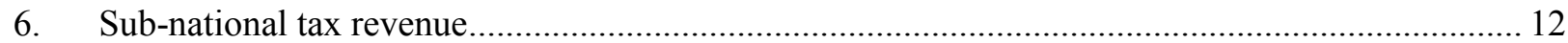

7. Composition of state and local tax revenue in selected federations............................................ 12

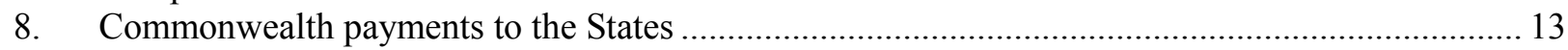

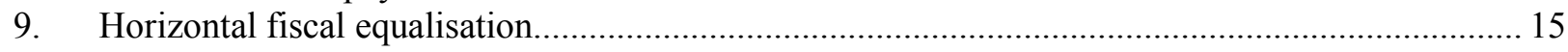

10. Consistency in health-care responsibility assignment across levels of government ...................... 21

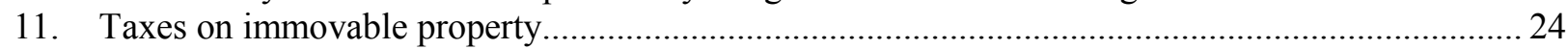




\section{Boxes}

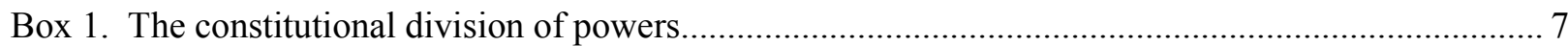

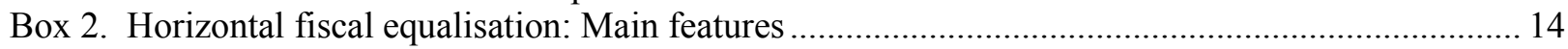

Box 3. Intergovernmental Agreement on Federal Financial Relations: Key provisions.......................... 16

Box 4. Vertical fiscal imbalance: Potential consequences for the efficient delivery of services ............. 22

\section{Recommendations}

Recommendations for improving federal-state relations 30 


\section{FEDERAL-STATE RELATIONS IN AUSTRALIA}

\section{By Vassiliki Koutsogeorgopoulou and Annamaria Tuske ${ }^{1}$}

Australia's inter-governmental fiscal relations have gradually moved towards greater centralisation. The division of responsibilities between central and state-level, and the attendant system for financing state governments through own revenues and transfers are important challenges in this regard. The paper discusses current issues in federal-state relations and lays out policy options for improvement.

\section{Australian inter-governmental fiscal relations: Main features and trends}

\section{The structure of government and constitutional division of powers}

Australia's federation comprises three levels of government: central (the Australian or "Commonwealth" government); state (six states and two territories with state-type powers); and local (562 local government authorities), which are established through state legislation. Local governments play a minor role by international standards, with their responsibilities mainly confined to local public works, waste disposal, town planning and welfare services (PC, 2005; Brown, 2012a).

Australia is a decentralised federation by Constitution (Box 1), with intention that federal and state levels independently exercise powers within their own areas of policy, thereby requiring little coordination (Fenna, 2007; Banks et al., 2012). The Commonwealth was assigned a "limited" and "limiting" list of responsibilities, including currency, customs and excise, and defence (Fenna, 2012a). States were to retain most domestic responsibilities, such as education, health and infrastructure. The two levels had concurrent jurisdiction in some areas, including most areas of taxation.

\footnotetext{
1. Vassiliki Koutsogeorgopulou is Economist on the Australia/Norway Desk in the Economics Department of the OECD; Annamaria Tuske is a statistician on the Desk. This paper is based on Chapter 2 of the 2014 OECD Economic Survey of Australia, published in December 2014 under the authority of the Economic and Development Review Committee (EDRC). The authors would like to thank Alvaro Pereira, Robert Ford, Piritta Sorsa, Philip Hemmings, Hansjörg Blöchliger and colleagues in other OECD Departments for valuable comments on earlier drafts. The report also benefited from comments from the Australian authorities. Special thanks go to Anthony Bolton and Mikel Inarritu for administrative assistance.
} 


\section{Box 1. The constitutional division of powers}

The Australian federation was established in 1901. Only the two higher tiers of the government - the Commonwealth (Australian Government) and the states - are established by the Constitution (the Commonwealth of Australia Constitutional Act 1900).

The Constitution assigns the Australian Government a specific set of powers (Fenna, 2012a). A small number of these are exclusive, such as: the power of determining rates of customs and excise duties, coinage, national defence. Other Australian-Government powers are to be exercised concurrently with the state governments, for example: taxation, apart from customs and excise duties; post and communication; trade; banking and insurance; and industrial disputes that extend across states. In case of inconsistency, the central government has legislative supremacy (OECD, 2006).

The fairly narrow set of Australian-Government constitutional powers means that state governments have considerable responsibilities including: health, education, housing and urban development, police and justice system, energy, agriculture, transport and public services. However, the Commonwealth government can have influence by drawing on its general powers, such as that of "corporation" (the right to legislate with respect to foreign corporations, and trading or financial corporations formed within the limits of the Commonwealth) and "external affairs" powers (Banks, et al., 2012). Regarding the latter, the Australian Government can still legislate, for example, in the area of environment for which it does not have constitutional responsibility, in support of any international environmental agreement (PC, 2005). Moreover, the constitution contains a clause allowing the Australian Government to grant financial assistance to states on terms and conditions it deems appropriate, which provides another mechanism for influence.

\section{Centralisation and extensive joint government responsibilities}

The balance of power has shifted towards central government over time, although the Constitution remains largely unaltered (Banks et al., 2012, Murray, 2012). This diverges from trends seen in comparable federations which have devolved responsibilities (Warren, 2006). To a large extent, centralisation in Australia has arisen from broad interpretation of the Commonwealth's enumerated powers by the High Court. For example, the Court's interpretation of "excise duties" to incorporate all taxes on manufacture, distribution, and sale of goods, barred states from levying sales taxes; and its decision in the second Uniform Income Case (1957), effectively confirmed the 1942 judgment that the Commonwealth's exclusive power over the income tax base (constitutionally a shared base) could continue after the war (Fenna, 2012b). The practical operation of the Australian federation has been further influenced by referenda (as on indigenous population affairs) and referral of state powers to the Commonwealth (as, for example, with industrial relations powers), as well as certain constitutional features, and in particular, the Commonwealth's right to grant financial assistance to the states on terms and conditions that it specifies (Box 1). Other reasons explaining the shift of power over time include the need for centralised policies in certain areas to meet socio-economic realities and challenges, the increasing complexity in the federal system, and, possibly, an inclination of voters to look at the central government to overcome perceived weaknesses in state/local service delivery (BCA, 2006; Fenna, 2012a). 
The growth of "tied" grants from the Commonwealth to the states increased federal control and led to a relatively high degree of shared functions between state and federal governments and a complex pattern of expenditure. Over time, the Commonwealth government became more active in areas that were once the domain of the states - sometimes called "co-operative" federalism (Banks, et al., 2012). At present, the two government levels are involved in most areas of public services (Figure 1).

Figure 1. Decomposition of government expenditure by function

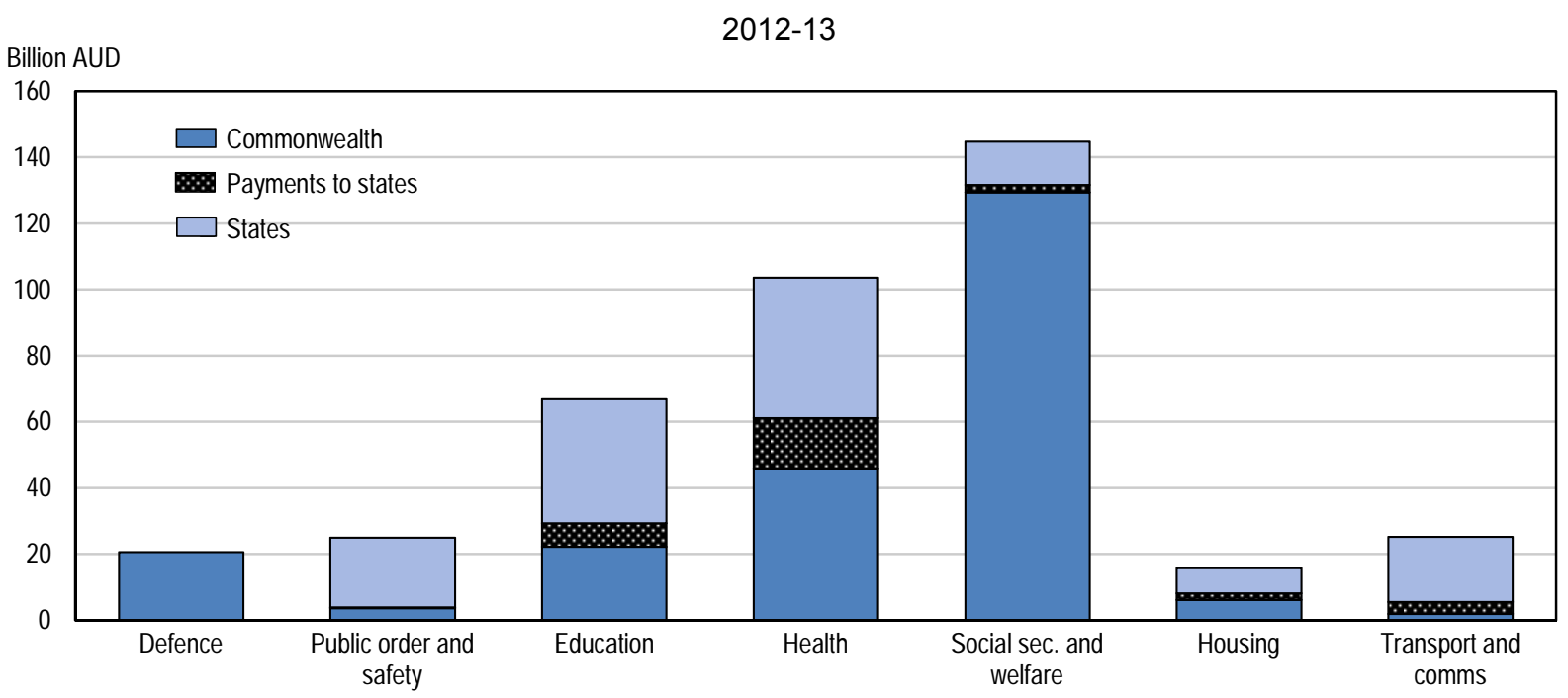

Source: Australian Bureau of Statistics (2014), Government Finance Statistics 5512.0; Commonwealth Final Budget Outcome 201213; Australian National Authorities.

Shared government functions are not an uncommon feature in federations. Australia stands out, however, with respect to the mix of responsibilities in the areas of health and education (Warren, 2006; Twomey and Withers, 2007). A study covering a number of federations (including Canada, Germany and Switzerland) concluded that responsibility for these two areas tends to be allocated almost exclusively to one level of government (Warren 2006). By contrast, in Australia (and to a lesser extent Austria) both central and state governments have major responsibilities (discussed below in detail) and roughly equal levels of spending (Figure 2). 
Figure 2. Expenses by government level in health and education in selected federations

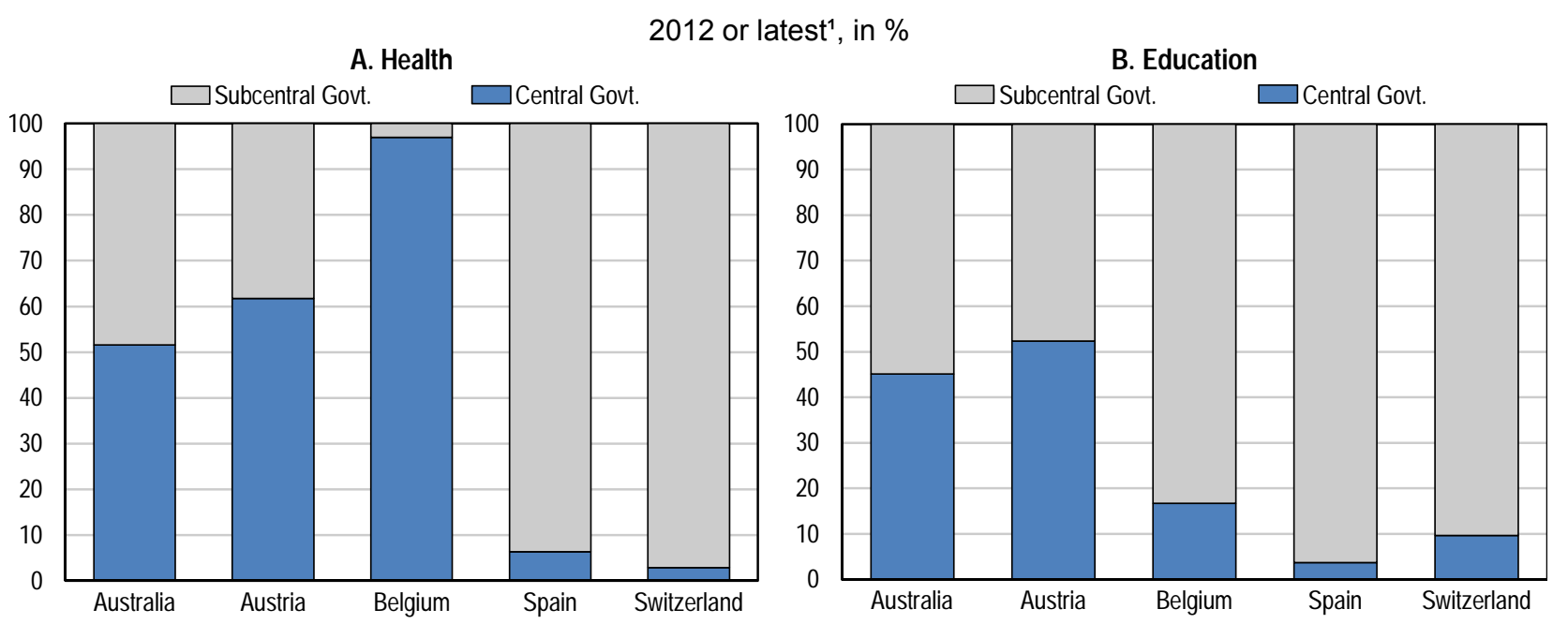

1. 2011 for Switzerland.

Source: IMF(2014), Government Finance Statistics (GFS) database.

\section{A relatively high vertical fiscal imbalance}

Australia's federation has long been characterised by a large vertical fiscal imbalance (VFI): state's own revenues are not sufficient to fund their spending responsibilities, while the revenue sources of the Australian Government are greater than its spending needs (Figure 3). In the federation's early days the imbalance was high because revenues from customs tariffs, an important revenue source at the time, was assigned exclusively to Commonwealth (Figure 3; Banks et al., 2012). Currently, sub-national spending (as a share of total government spending) is similar to that in the United States and Spain, but less than in Switzerland or Canada (Figure 4). Australia's states finance only around half of their spending responsibilities from "own revenues", with the remainder being covered by federal grants. However, an important reservation is the status of the Goods and Services Tax (GST) which is governed by national legislation and administered centrally but all revenues are passed onto the states.

The central government raises around $80 \%$ of total tax revenue, when the GST is taken into account, and has control over some broad based taxes including, personal and corporate income, in addition to customs and excises (Figure 5). In contrast, state taxes account for around $15 \%$ of the national tax revenue, a comparatively small share in international comparison (Figure 6); local governments (property tax) collect the rest. State revenues are mostly taxes on property (including immovable property and financial and capital transactions) and payroll taxes. These are also potentially broad tax bases. Australia is among the few OECD countries levying payroll taxes (Figure 7). In addition, there is no co-occupancy of tax bases by the Commonwealth and the state governments, unlike in other more decentralised federations, such as Canada and Switzerland (for example, income tax in Canada) (OECD 2006; Bird and Smart, 2010). Nevertheless, Australian states have the right to set their own tax rates and bases for taxes they control, so at least in principle, sub-national government revenues could play a bigger role. 
Figure 3. Vertical fiscal imbalance over time and across countries ${ }^{1}$

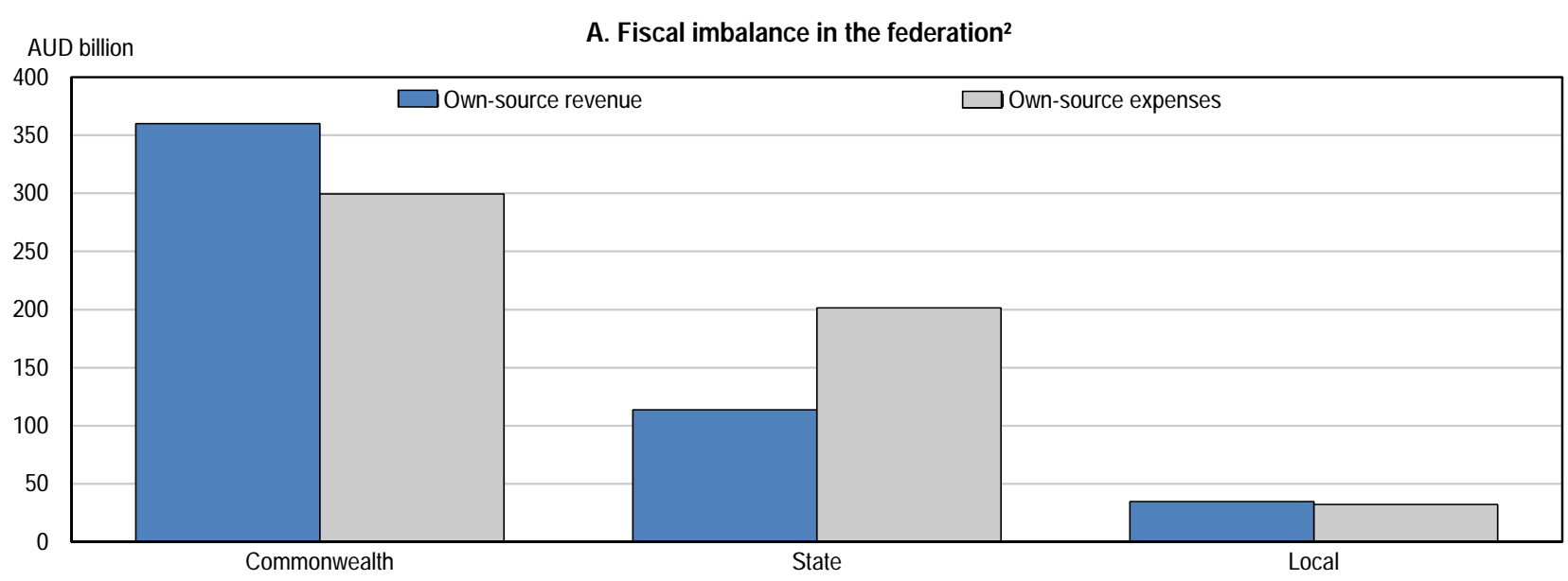

B. Federal transfers to the states as a per cent of total state revenue
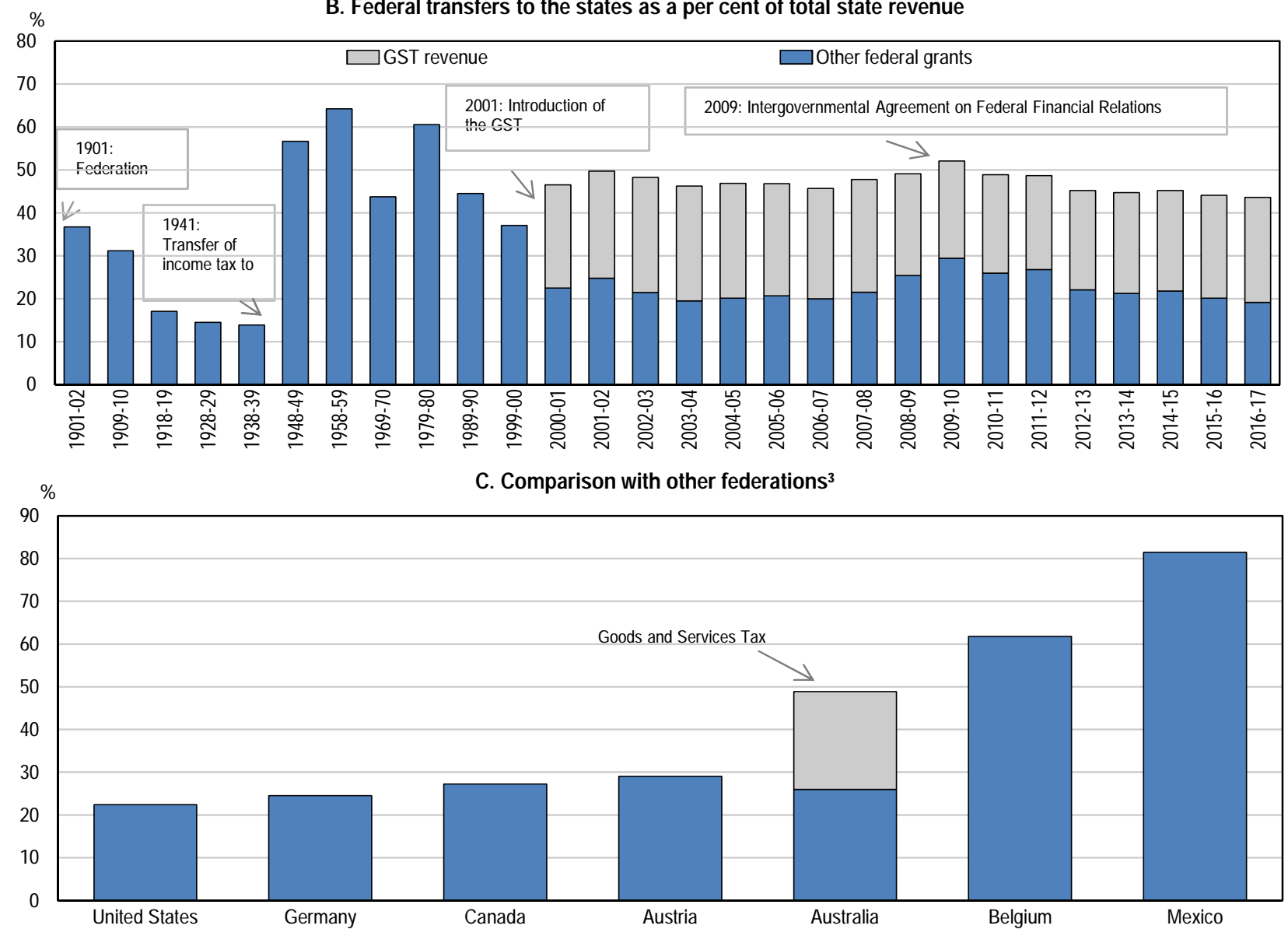

1. The vertical fiscal imbalance (VFI) is defined as the total of federal payments to total sub-national revenue. Data starting from 2013-14 refer to estimates.

2. Own-source revenue is defined as total revenue minus grant revenue; own-purpose expenses are defined as total expenses minus grants to other levels of government. Data refer to the financial year 2012-13.

3. For Australia, VFI is the share of Commonwealth payments in total state revenue. Data refer to 2011 and in the case of Canada to 2010 .

Source: Australian National Authorities; ABS, Government Finance Statistics 2011-12 (cat. No. 5512.0); Australian Government (2010), Budget paper No. 3 : Federal Financial Relations 2010-11 and Final Budget Outcome papers 2009-10 to 2011-12; International Monetary Fund (2013), Government Finance Statistics Yearbook; OECD, Fiscal Decentralisation database. 


\section{Figure 4. Fiscal decentralisation}

Sub-national shares of revenue and expenditure in per cent of total general government, 2012 or latest year ${ }^{1}$

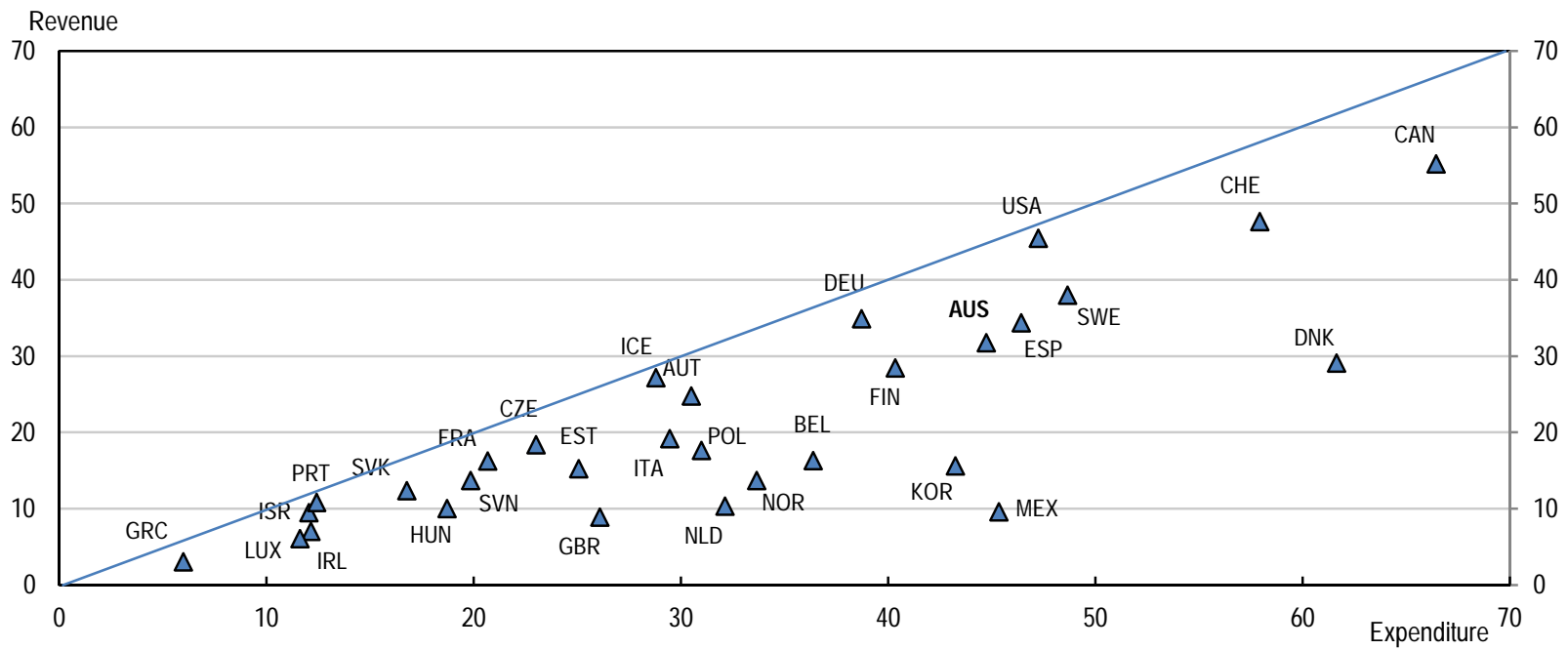

1. Data refer to 2011 for Korea and Mexico and to 2010 for Canada. Revenue does not include intergovernmental transfers. For Australia, data refer to the financial year 2011-12.

Source: OECD (2014), Fiscal Decentralisation database; ABS, Government Finance Statistics 2011-12 (cat. No. 5512.0).

Figure 5. Sources of tax revenue in Australian federation

Per cent of total ${ }^{1}, 2012-13$

\section{A. Total taxation revenue AUD 416 billion}

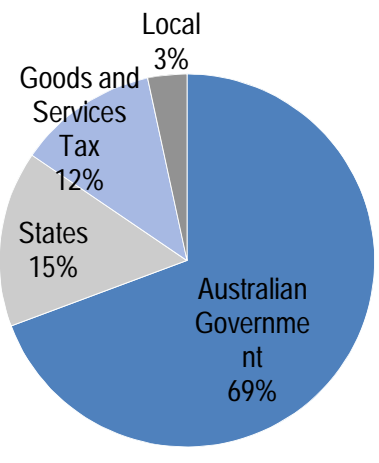

B. Australian Government (Commonwealth) AUD 288 billion $^{2}$

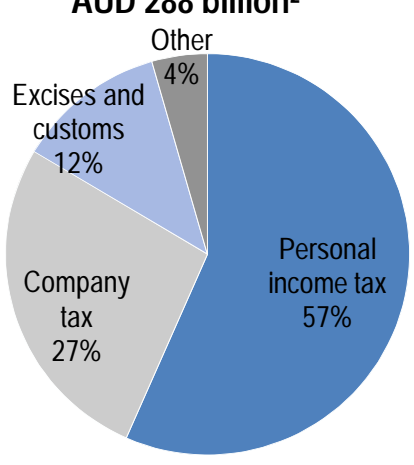

\section{States AUD 63 billion}

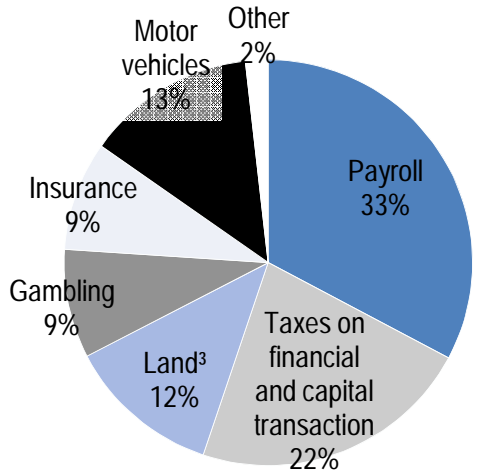

1. Figures are rounded.

2. Goods and Services taxes are excluded.

3. Land taxes comprise all taxes on immovable property.

Source: ABS (2014), Taxation Revenue Australia 2012-13 (cat. No. 5506.0). 
Figure 6. Sub-national tax revenue ${ }^{1}$

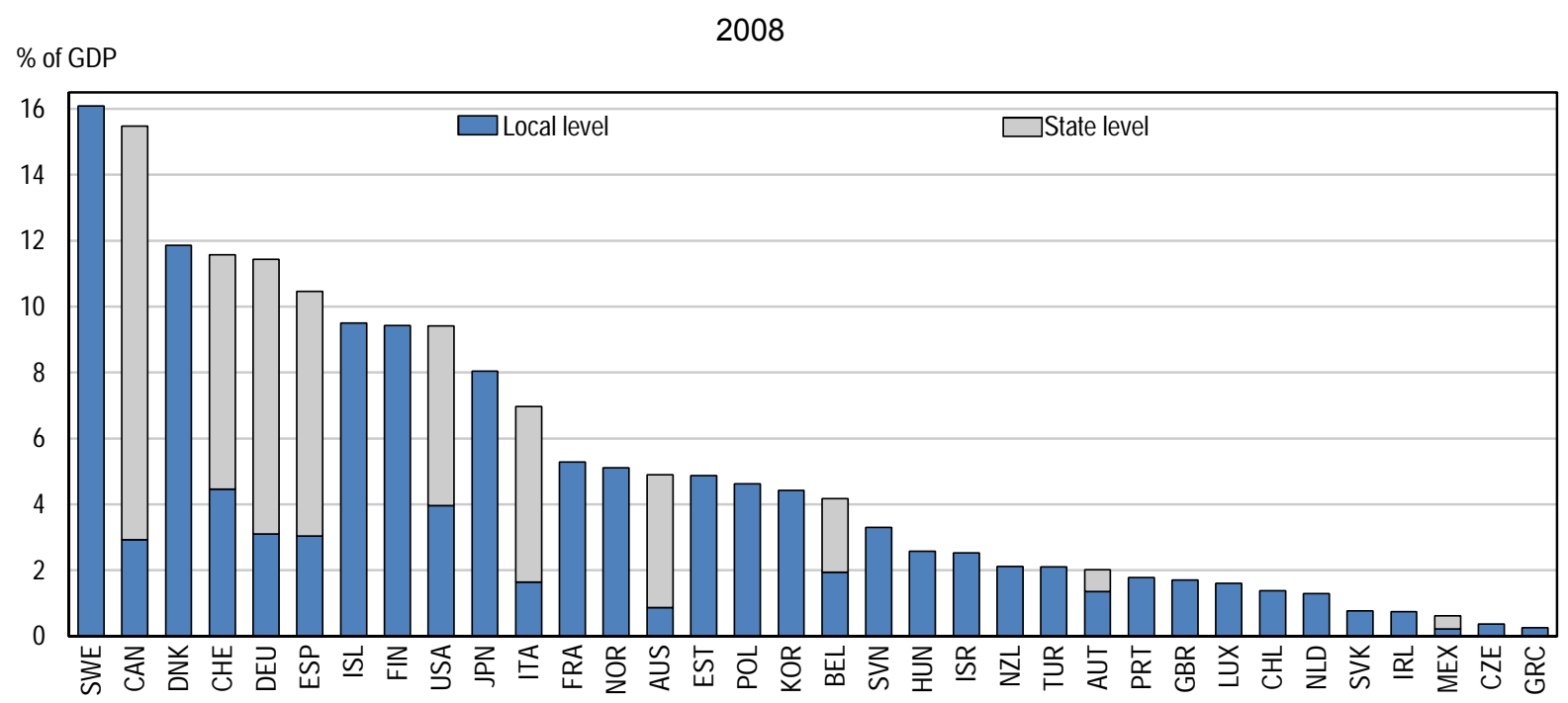

1. Taxes where sub-central governments have power to set the tax base and /or the tax rates, as a percentage of GDP. Local governments in the United States have a wide variety of taxing powers but it is not possible to identify the share of each.

Source: OECD (2014), Fiscal Decentralisation database.

Figure 7. Composition of state and local tax revenue in selected federations

As per cent of total tax revenue, 2012 or latest $^{1}$

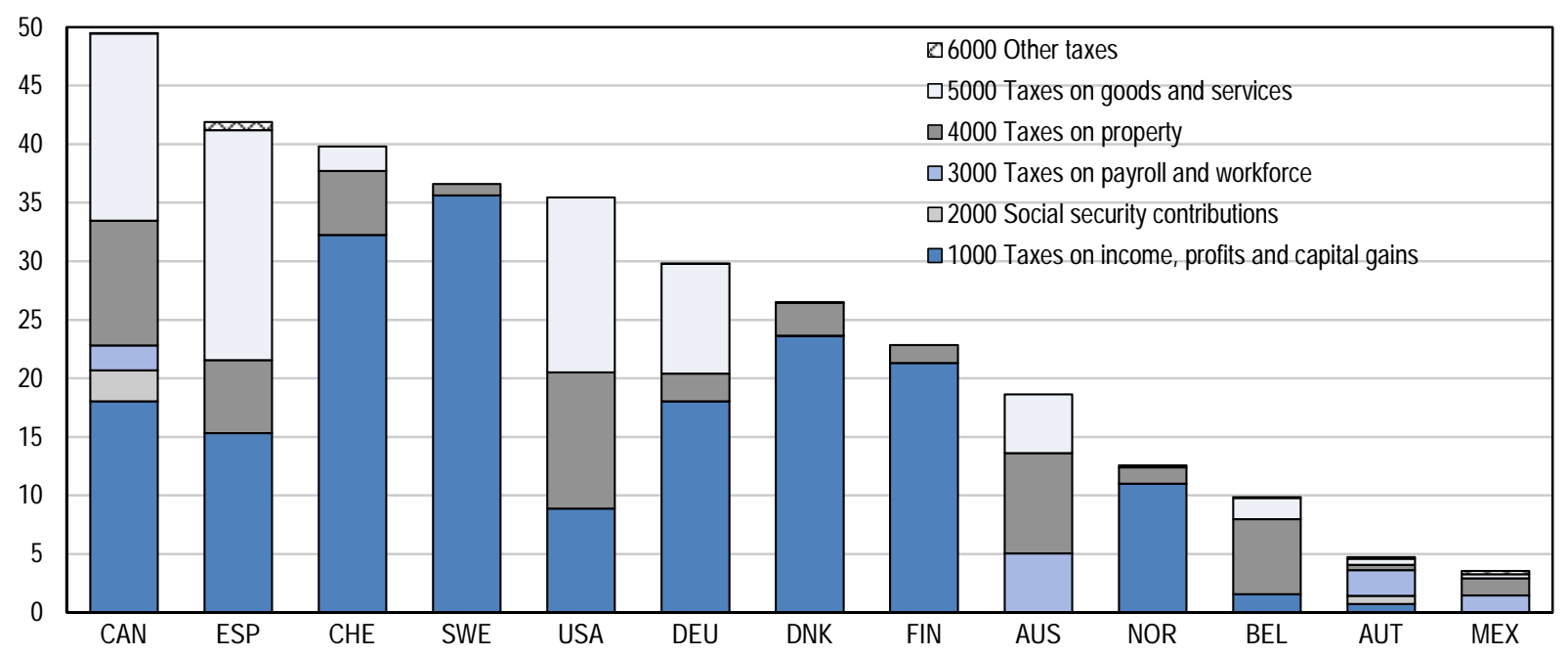

1. 2011 for Australia.

Source: OECD (2014), Revenue Statistics Database.

Large vertical imbalances necessarily imply sizeable transfers from central to sub-central government. In Australia there is an extensive system of inter-governmental grants comprising general purpose (nonearmarked) assistance (mainly from GST revenues) and specific purpose payments (SPPs). Under the current intergovernmental agreement (discussed below), the Commonwealth provides to the states specific payments with a varying degree of conditionality. The National Specific Purpose Payments (NSPPs), for example, are only conditional on spending in the relevant service sector, while the National Partnership Payments (NPPs) are more narrowly focused and carry more conditionality (Figure 8). Specific purpose 
payments are most widely used in health and education, and in 2013-14, they accounted for around half of the total Commonwealth payments to states (equivalent to approximately around 3\% of GDP), partnership payments comprising around a third of all specific payments (Figure 8).

\section{Figure 8. Commonwealth payments to the states}
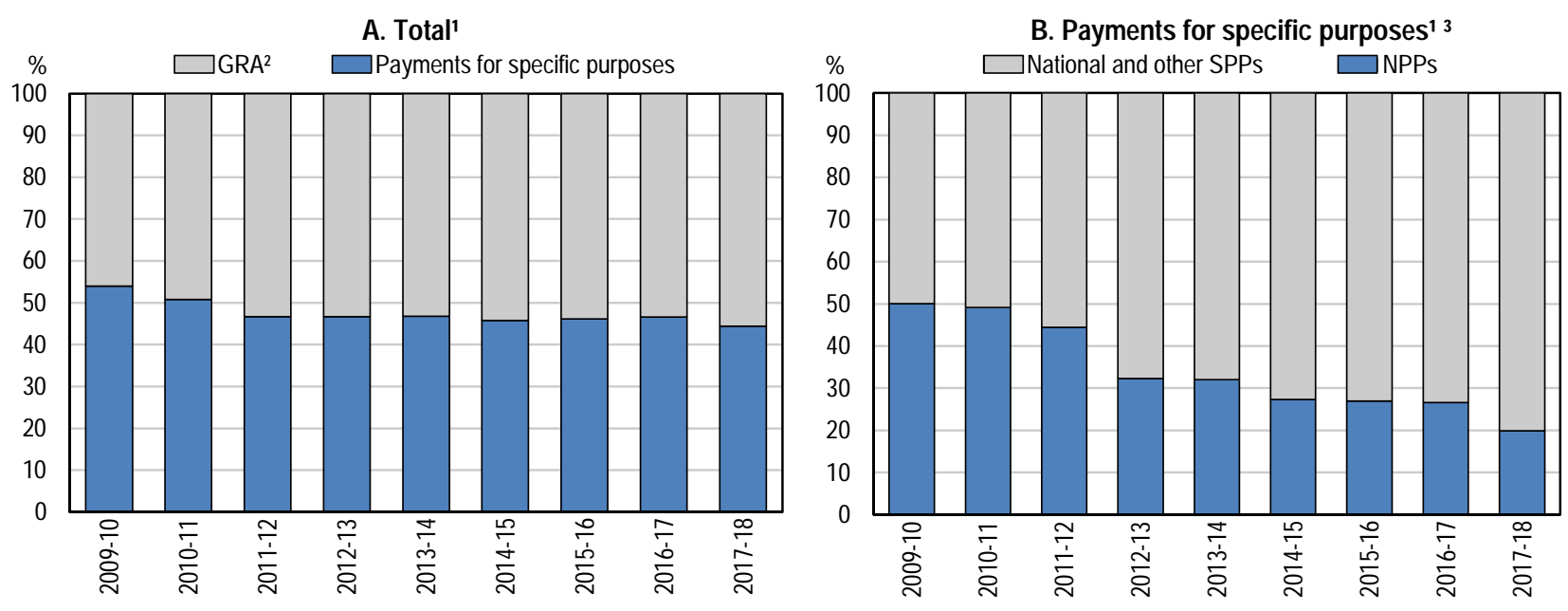

C. Shares of payments for specific purposes by sector ${ }^{3}$

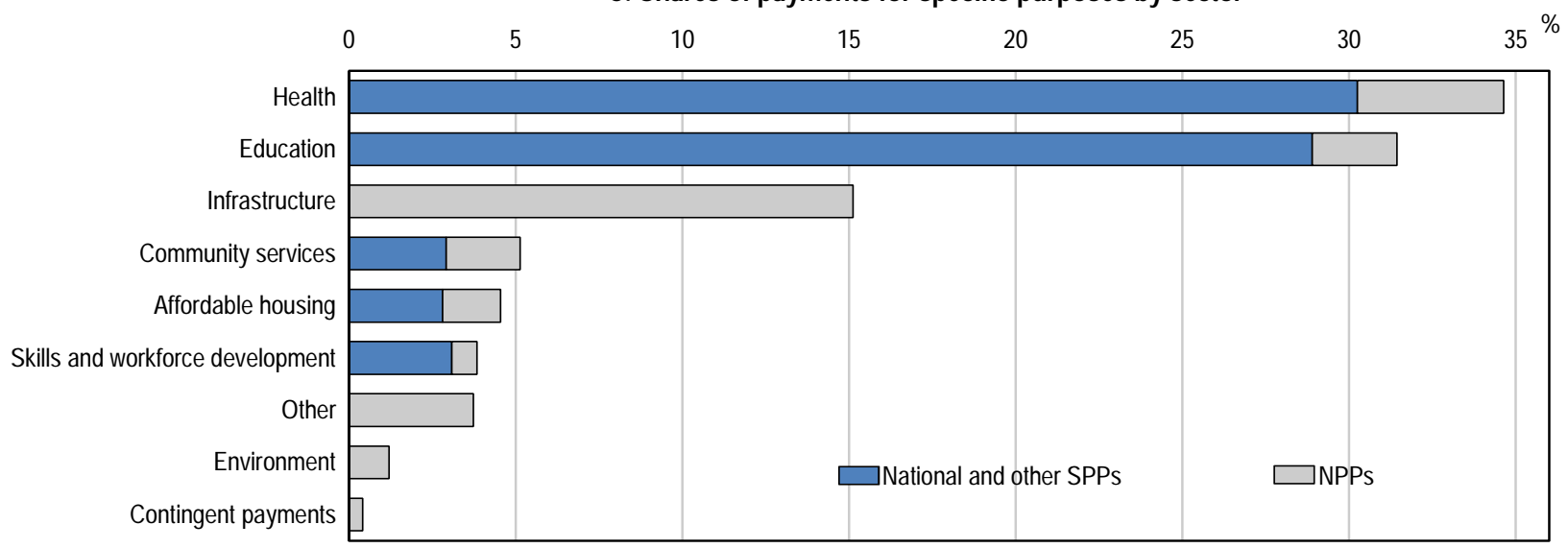

1. Starting from 2014-15, values refer to estimates.

2. General revenue assistance (GRA) includes GST payments.

3. National and other SPPs refer to National Specific Purpose Payments (NSPPs), as well as to the current arrangements (National Health Reform and Students First funding) for healthcare and schools which replaced the former National SPPs for these sectors in 2012 and 2014, respectively. NPPs refer to National partnership payments.

Source: FBO for financial years 2009-10 to 2012-13 and Budget paper No.3 for 2014-15.

The large vertical imbalance is central to the political economy of Australian federalism. It provides the Commonwealth government with considerable de facto power over states because of their reliance on transfers to balance their books. For the states this reliance means reduced autonomy, but it does have advantages. The transfers are, in effect, a statement of implicit guarantee by the federal government for states' finances. This means that pressuring the federal government for funds can be a more feasible and attractive option than local taxation, which may partly explain why state governments have narrowed their tax bases through exemptions (see below). Thus, the vertical fiscal imbalance effectively reflects a particular "equilibrium" of current de facto powers and responsibilities between federal and state governments. 


\section{Horizontal fiscal imbalances and the equalisation process}

GST revenue is distributed across the states on the basis of the principle of horizontal fiscal equalisation (HFE) (Box 2). This aims to ensure that states have the same capacities to deliver services (Banks et al., 2012). Horizontal imbalances are common in a federation, reflecting differences in the revenue raising capacity and/or delivery costs among the states (Australian Government, 2013). Recent estimates by the Commonwealth Grants Commission (CGC) suggest, for instance, that, in 2011-12, the revenue-raising capacity of the Australian states ranged between $79 \%$ (Tasmania) and 146\% (Western Australia) of the national average, while cost differences across states were within $10 \%$ of the national average (excluding the Northern Territory) (CGC, 2013). Western Australia has the greatest revenue capacity, predominately, but not exclusively, due to its vast mining revenue. Indigeneity is an important cost factor for Northern Territory.

\section{Box 2. Horizontal fiscal equalisation: Main features}

The Commonwealth Grants Commission (CGC) -an independent advisory body established in 1933- recommends how revenues from GST should be distributed among the states to achieve horizontal fiscal equalisation (HFE). The Commission's definition of equalisation is to provide each state with funding such that: "each would have the capacity to provide services and the associated infrastructure at the same standard, if each made the same effort to raise revenue from its own sources and operated at the same level of efficiency" (CGC, 2013; p. 30).

The equalisation rests broadly on three principles: $i$ ) the process opts to equalise the fiscal capacity of the states, rather than the performance or outcomes they achieve, with states being free to choose how to spend their GST revenue ii) states are equalised to average standard - no judgment is made by the Commonwealth Grants Commission about the level of service that might be appropriate or appropriate benchmarks; and iii) equalisation is "policy neutral" - own policies or choices should not directly influence a state's share of GST revenue (OECD, 2006).

Under the current equalisation system, the distribution of GST revenue is based on the per capita relativities, recommended by the Commonwealth Grants Commission. The relativities determine how much revenue of the GST pool each state receives compared to an equal per capita (EPC) share (Australian Government, 2011). If the states had the same capacities to raise revenue and deliver services, GST would be distributed on the basis of a state's population. Because there are different revenue and cost drivers in each state, however, that are beyond their control, then under the equalisation system some states receive more than their EPC share (the relativity is greater than one) and others less (the relativity is less than one) (Australian Government, 2011).

The Commonwealth Grants Commission uses a complex methodology to calculate the per capita relativities (as discussed below). The approach takes account of differences in per capita revenue-raising capacity and differences in spending "needs" (i.e. the per capita amounts required to be spent by the states in providing an average standard of government services). Various control variables are used in the calculation, including population structure and wages. The most important factors driving differences in the relativities are differences in fiscal revenues from mining and differences in the size of indigenous populations across the states (Clemens and Velhuis, 2013; Kirchner, 2013). The latter is influential in the calculation because of high unemployment and low earnings in these communities and the additional public spending in regular and targeted programmes endeavouring to resolve these issues and other socio-economic problems.

Calculation of the relativities incorporates the majority of specific purpose payments to the states, treating them as revenue and adjusting the GST shares accordingly (Australian Government, 2011). The equalisation process, thereby, effectively "overrides" the distribution of payments for specific purposes by the federal government (Clemens and Velhuis, 2013). Some specific purpose payments, however, do not impact GST sharing relativities, either because they are "excluded" by the Commonwealth in its terms of reference given to the Commission, or, effectively excluded due to decisions of the Commission (Australian Government, 2011). Treasury estimates suggest, for example, that around $17 \%$ of federal payments to the states had no impact on the calculations of relativities in 2009-10 (Australian Government, 2011). Some imbalances in GST allocation, therefore, may be partially offset by other transfers to the states that are not factored into the equalisation system.

The CGC updates the relativities each financial year, and undertakes broader reviews of its methodology every five years. The new review is due to be released in 2015. 
The equalisation process redistributes funds among states (Figure 9). Overall, according to the budget estimates, in 2014-15 around 10\% (or AUD 5.6 billion) of the GST payments are expected to be redistributed among the states as compared to a notional distribution on an equal per capita basis (Australian Government, 2014a).

Figure 9. Horizontal fiscal equalisation

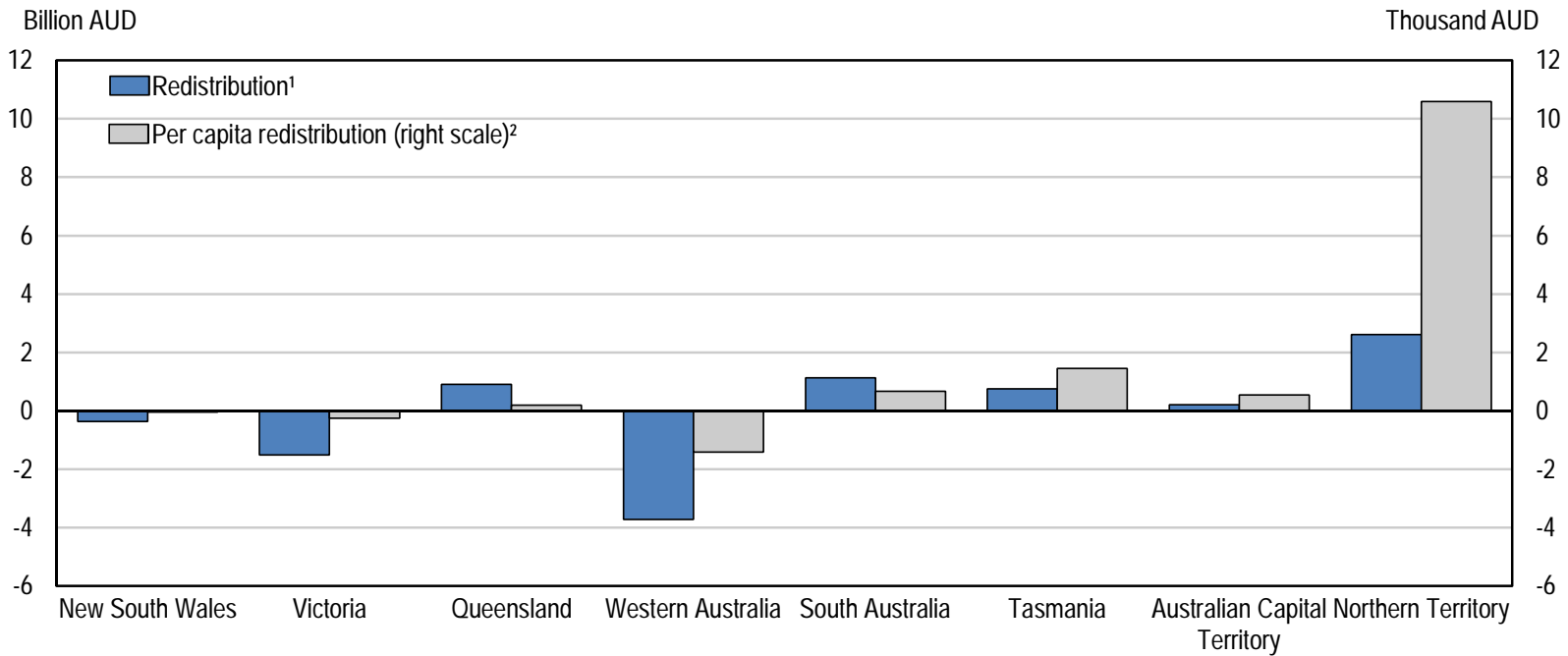

1. Redistribution refers to the difference between a state's distribution of the Goods and Services Tax (GST) revenue using the Commonwealth Grants Commission's relativities (see Box 2) and a notional distribution of GST on a per capita basis.

2. Per capita redistribution refers to redistribution divided by population.

Source: Australian Budget 2014-15, Budget Paper No. 3.

\section{Division of responsibilities in the provision of public services}

The relatively high degree of shared functions between government levels in Australia raises challenges. Some overlap may be beneficial if it provides greater choice or better services by addressing perceived gaps, or broadens access to services. Some states, for example, provide services to assist older people's transition from hospital to home, notwithstanding Commonwealth action in this domain (PC, 2005). However, extensive joint government involvement, can blur the lines of responsibility, increasing the risk of administrative duplication, waste and cost, and blame-shifting among government levels (OECD, 2006; BCA; 2006; NCA, 2014). Potentially, this results in reduced cost-efficiency and quality of public services, and there certainly appear to be important instances of this (discussed below). The COAG Reform Council (the Council) recently highlighted the increasing pressures on Australia's intergovernmental relations from widespread shared responsibilities (CRC, 2013a).

A 2008 Intergovernmental Agreement on Federal Financial Relations (IGA) attempted to better specify government roles and responsibilities in each National Agreement (Box 3). This was the first time that the Commonwealth and states had documented (with a varying degree of descriptions across and within agreements) their individual and joint responsibilities for specific sectors (CRC, 2013a). The overarching aim of the agreement was to improve the quality, efficiency and effectiveness of government services, among other things, through a more co-operative policy development and enhanced accountability to the public.

The 2008 IGA led to some clarification of roles and responsibilities, e.g. in the area of business regulation (O'Meara and Faithfull, 2012). However, a recent monitoring report by COAG Reform Council (the Council) highlighted, for instance, that, in general, the delineation of roles between federal and state 
government in the National Agreements had not been implemented, calling for further efforts to reach consensus on the issue (CRC, 2013a). The recent National Commission of Audit (NCA) has also indicated continuing difficulties (NCA, 2014). For example, health care faces some of the greatest challenges of coordination, and many areas of education also suffer from lack of clarity and overlap of government roles. Public spending on these two sectors accounted for more than 13\% of GDP in 2012-13. Dysfunctional federal-state shared responsibilities were also identified by the Commission in other areas, notably housing and infrastructure.

\section{Box 3. Intergovernmental Agreement on Federal Financial Relations: Key provisions}

The Intergovernmental Agreement on Federal Financial Relations (IGA) was endorsed by the Council of Australian Governments (COAG) in November in 2008 and became effective in January 2009. It provided increased federal funding to states and initiated several reforms, notably:

- A new federal-state financial framework to rationalise the number of tied grants and increase state funding flexibility. The framework provides financial support for the states through: i) untied general revenue assistance (mainly GST); ii) National Specific Purpose Payments (NSPPs) to be spent in key service delivery sectors, with each payment being associated with a National Agreement; ${ }^{*}$ and iii) a new form of payment National Partnerships Payments (NPPs) - to fund specific projects and reward states that deliver on nationally significant reforms or service improvements. These payments are granted to the states only upon the achievement of milestones or performance benchmarks. Their terms and conditions are specified by the National Partnership Agreements (NPs). This new framework represents a significant rationalization of the tied grants, replacing the former numerous specific purpose payments with a small number of much less prescriptive grants (Banks, et al., 2012; Blöchliger and Vammalle, 2012).

- Greater clarity in roles and responsibilities. The National Agreements reached by the Commonwealth and states under the new framework specify the roles and responsibilities of levels of government, along with objectives, outputs, outcomes and performance indicators for each sector.

- More transparent public performance reporting through enhanced outcome and performance, based on monitoring and assessment via the COAG Reform Council (the Council), which ceased to operate in June 2014.

- Centralised funding arrangements. Under the IGA framework, payments are processed by the Commonwealth Treasury and paid directly to state treasuries, which have the responsibility for their distribution (Australian Government, 2009a). Previously, funding was provided, instead, to relevant state agencies by the Commonwealth portfolio departments, and each payment had each own administrative arrangement.

\footnotetext{
* Two former NSPPs have been suspended. Healthcare and schools funding, in particular, are currently under different arrangements - National Health Reform and Students First funding - in effect since 2012 and 2014, respectively (Australian Government, 2014a).
}

\section{Health care}

The fragmentation and complexity of the health system has long been a source of tension and inefficiency in Australia (Fenna and Anderson, 2012). The configuration of federal and state responsibilities is at the heart of the problem. Most notably, the Commonwealth funds general-practitioner services while the states are responsible for segments of primary service plus public hospitals - managing, running and part-funding them (Table 1). This structure results in co-ordination and cost- and blameshifting problems (Australian Government, 2010a; Fenna and Anderson, 2012). There may be an incentive, for example, for public hospitals to refer discharged patients to their general practitioner, rather than providing post-hospital services directly, thereby shifting the cost from the states to the Commonwealth (OECD, 2006; Anderson, 2012). On the other hand, difficulties in accessing general practitioners may cause patients to resort to public-hospital emergency wards for primary care services, thereby shifting the cost from the Commonwealth to the states. A government report in 2010 concluded that the cost and blame 
shifting means that a large number of patients fall through service gaps, or receive poorly coordinated services, particularly in remote or highly disadvantaged areas (Australian Government, 2010a). The complexity of the health system also makes it difficult for patients to work out which level of government is accountable for their care.

Clarifying responsibilities has been a key objective of healthcare reform in recent years (Fenna and Anderson, 2012). Building on previous initiatives, an agreement in 2010 (Health and Hospitals Network Agreement), endorsed by all states apart from Western Australia, attempted to remap the sector, with the federal government taking full funding responsibility for primary health and aged care, and becoming the majority funder of public hospitals (while holding back a proportion of the GST revenue to the states) (Australian Government 2010b; Anderson, 2012). In addition, under the 2010 Agreement the operational management of public hospital and accountability for local delivery was devolved to Local Hospital Networks (LHNs), established by the states (COAG, 2010). The states remained the managers for public hospitals (Fenna and Anderson, 2012). Not all of the changes entailed in the 2010 agreement were implemented, however.

The subsequent National Health Reform Agreement (NHRA) of 2011, currently in force, is implementing reforms in aged care (Table 1) and the devolution to Local Hospital Networks. However, the changes giving the federal government greater funding responsibilities in primary and hospital care did not happen (the latter reflecting the fact that the 2010 provision for a reduction in GST payments to states, in exchange for an increased federal funding for public hospital services, was removed) (Anderson, 2012). Nevertheless, the federal funding contribution to hospitals increased in the 2011 NHRA, which will be based largely on actual activity levels, rather than on a block grant basis as in the past (Rimmer, 2012). Hospital funding to the states, therefore, is currently linked directly to the number and type of patients treated (though, on the basis of the May 2014 budget, an indexation rather than an activity-based funding arrangement will apply from 2017). In addition, current arrangements require funding for hospitals to be channelled to a single national pool to be managed by independent bodies that have to report regularly on the performance of hospitals and health services (Australian Government, 2012a; Rimmer 2012).

The 2011 National Health Reform Agreement increases the transparency and efficiency of hospital funding and services. The introduction of the Local Hospitals Networks, for instance, is expected to reduce some overlaps and duplication of services that would come from individual hospitals operating independently from each other. However, there are concerns that the increased focus on hospitals will adversely affect primary and preventive care, in addition to reducing the flexibility of federal funding (CRC, 2013a). Importantly, complexity and unclear roles and responsibilities in the healthcare sector remain, creating scope for inefficiencies to occur. Recent industry analysis has indicated that, even after several years of reforms in healthcare, a "dysfunctional fragmentation" between the Commonwealth and state governments (and private insurers) persist, as is the "blame game" (CEDA, 2013).

\section{Education}

In the school sector, joint federal-state responsibilities and parallel state systems have resulted in a complex setup. Constitutionally, schools are a state responsibility but the Commonwealth has taken an increasing role via school funding, providing today around a quarter of public funding to schools. The central government provides funds to non-government (private) schools, while the states largely fund government (public) schools (Table 1). There is also a significant overlap in regulation, with the national agreements on schooling generating administrative red tape and compliance costs for the states, according to the National Commission of Audit (NCA, 2014). 
ECO/WKP(2015)16

Table 1. Commonwealth-state responsibilities for healthcare and education and training

\begin{tabular}{|c|c|c|}
\hline Functional area & Commonwealth & States \\
\hline \multicolumn{3}{|c|}{ Health $^{1}$} \\
\hline \multirow[t]{6}{*}{ Health care } & \multirow{2}{*}{$\begin{array}{l}\text { Funding and administrating Medicare (Australia's } \\
\text { national public health insurance scheme) which } \\
\text { covers: medical services (including visits to GPs), } \\
\text { prescription pharmaceuticals and public hospital } \\
\text { treatment (co-funded with the states). }\end{array}$} & $\begin{array}{l}\text { Delivering and managing of a range of public } \\
\text { health services, including public hospitals, } \\
\text { community health and public dental care. }\end{array}$ \\
\hline & & Contributing to funding of the above services. \\
\hline & $\begin{array}{l}\text { Regulation of health services, products and health } \\
\text { workforce. }\end{array}$ & \multirow[t]{4}{*}{$\begin{array}{l}\text { Primarily responsibility for the regulation of } \\
\text { health care providers and private health facilities. }\end{array}$} \\
\hline & National health policy leadership. & \\
\hline & Rebates to private insurance holders. & \\
\hline & $\begin{array}{l}\text { Funding for improved access to primary care, } \\
\text { including indigenous-specific primary health. }\end{array}$ & \\
\hline \multirow[t]{3}{*}{ Aged care services } & \multirow{2}{*}{$\begin{array}{l}\text { Funding and regulating aged care services, including } \\
\text { packaged community care, residential aged care } \\
\text { and basic community care services for people } \\
65 \text { years and over (or } 50 \text { years and over for } \\
\text { Indigenous Australians). }\end{array}$} & $\begin{array}{l}\text { Funding and regulating basic community care } \\
\text { services for people under } 65 \text { years and over } \\
\text { ( } 50 \text { years and over for Indigenous Australians). }\end{array}$ \\
\hline & & $\begin{array}{l}\text { Funding packaged community and residential } \\
\text { care for the specific age groups above. }\end{array}$ \\
\hline & $\begin{array}{l}\text { Funding specialist disability services (delivered by } \\
\text { the states) for the specific age groups above. }\end{array}$ & Regulating specialist disability services. \\
\hline \multicolumn{3}{|c|}{ Education and training } \\
\hline \multirow[t]{4}{*}{ School education } & \multirow{4}{*}{$\begin{array}{l}\text { Majority government funder for non-government } \\
\text { schools and provision of supplementary funding to } \\
\text { government schools. }\end{array}$} & $\begin{array}{l}\text { Providing schooling (and pre-schooling) to all } \\
\text { children at the eligible age. }\end{array}$ \\
\hline & & $\begin{array}{l}\text { Majority funder of government schools and } \\
\text { provision of supplementary funding to non- } \\
\text { government schools. }\end{array}$ \\
\hline & & Regulation of non-government schools. \\
\hline & & $\begin{array}{l}\text { Responsibility for school policies, including } \\
\text { control of teacher wages, hiring and firing } \\
\text { decisions, and curriculum design (with a degree } \\
\text { of Commonwealth co-ordination). }\end{array}$ \\
\hline \multirow[t]{5}{*}{ Tertiary education } & $\begin{array}{l}\text { Provides the majority of public funding for higher } \\
\text { education. }\end{array}$ & \multirow{5}{*}{$\begin{array}{l}\text { Primary responsibility for the delivery of VET } \\
\text { (with most states adhering to agreed principles } \\
\text { for the development of a national training } \\
\text { market). } \\
\text { Majority funder for VET. Co-funds for } \\
\text { apprenticeships. } \\
\text { Provision of only a small amount of funding to } \\
\text { some universities. }\end{array}$} \\
\hline & $\begin{array}{l}\text { Responsibility for policy and regulation of higher } \\
\text { education institutions and accreditation of some }\end{array}$ & \\
\hline & higher education courses. & \\
\hline & $\begin{array}{l}\text { Provision of supplementary funding for vocational } \\
\text { education and training (VET). Funding support for } \\
\text { apprenticeships (along with the states). }\end{array}$ & \\
\hline & $\begin{array}{l}\text { Provision of financial assistance for specific } \\
\text { educational programmes and categories of students. }\end{array}$ & \\
\hline
\end{tabular}

1. All three levels of Australia, along the private sectors, are involved in the health sectors but most activity performed by the Commonwealth and state government.

Source: National Authorities; OECD (2006); ABS (2012); NCA (2014).

Recent reforms that introduced a needs-based school funding model have not fully solved complexity and inconsistency. Instead of a national funding model, the government and non-government school sectors have their own approaches to allocating funding to schools. To illustrate the complexity: there are currently a Commonwealth model, 8 different state models, and a number of different models for schools in the private sector (NCA, 2014). Incoherent and opaque funding arrangements make it difficult to determine how individual schools are funded, with potential adverse effects on efficiency (OECD, 2013a). 
At the tertiary level, there is a considerable state-Commonwealth overlap in the vocational education and training sector (VET) including in the areas of regulation (where some states use the national regulator, while others maintain a state regulator); provision of incentive payments to employers; and student loans and subsidies. Also, multiple and fragmented funding arrangements, along with the multiplicity of state and national programmes, compromise funding accountability and increase administrative costs, with implications for efficiency and responsiveness, according to recent reports (Skills Australia, 2011; NCA, 2014).

The National Commission of Audit assesses that the VET outcomes are weak relative to the public money spent (approximately $0.6 \%$ of GDP) on the sector, and the completion rates for trade apprentices, for example, was less than $60 \%$ in 2012 (NCA, 2014). Overlaps between the Commonwealth and states in terms of VET funding and programmes may also undermine a fast move towards demand-driven, entitlement-based vocational system, discussed in the previous Survey (OECD, 2012a). Cross-state differences with regard to skills recognition also reduce the responsiveness of VET to changing needs by impeding labour mobility. For many occupations, a license acquired in one state does not entitle an individual to work in another (NCA, 2014). There is further a lack of streamlined regulatory and governance frameworks between tertiary education institutions (including both VET and higher education), which also creates duplication and inconsistency, according to a recent report (ACPET, 2013).

\section{Other sectors}

Overlapping and duplicative responsibilities are also evident in other sectors, according to the recent report of the National Commission of Audit (NCA, 2014). The duplication of the Commonwealth and state programmes for Australia's indigenous population (funded almost equally by the Commonwealth and states), for instance, is an area of concern, especially as socio-economic gaps between indigenous peoples and the rest of the population remain, despite several decades of policy attention.

Joint government involvement also raises issues in the housing area. The states, with a constitutional power in housing, provide public housing and address homelessness, in co-operation with communitybased organisations (NCA, 2014). However, Commonwealth plays a significant role, providing payments to the states for affordable housing and homelessness and direct rent assistance to households (excluding public tenants). This complex pattern of shared functions creates duplication of effort and administrative burden via the reporting requirements attached to Commonwealth-state agreements for affordable housing and homelessness. According to existing reports, success has been limited so far in these two areas, and especially, in improving housing affordability outcomes at the national level (CRC, 2012, 2013b; NCA, 2014).

Federal-state arrangements in infrastructure are also problematic according to NCA (2014), leading to an extensive institutional and regulatory duplication. Ownership and maintenance responsibilities generally reside with the states but the Commonwealth contributes significantly to funding of major projects. Recent reforms, including an improvement in economic planning, through reforms to Infrastructure Australia, an oversight body established in 2008 (OECD, 2012a; Australian Government, 2014b), should help overcome some of the difficulties by enhancing clarity of responsibilities. In the energy sector, under the Australian Energy Market Agreement the Commonwealth and states have joint policy responsibilities and national regulatory arrangements and institutions for the national energy market have been established. A White Paper on the energy sector (prepared in 2014) is, amongst other things, assessing the appropriate role for government. 
There are also instances of good inter-governmental co-operation, however. The current level of cooperation on innovation policy, for example, is effective, according to the authorities. The federal and state governments also work collaboratively to pursue water reform. For example, between November 2009 and January 2010 a set of Water Management Partnership Agreements were completed between the Commonwealth and the Murray-Darling Basin States, while in early-2014, the two parties signed the Intergovernmental Agreement on Implementing Water Reform in the Murray-Darling Basin.

\section{Potential reform options for better allocation of roles and responsibilities}

Being clear about which government level has responsibility for what is essential for effective action and public service efficiency, as well as enhanced accountability to the public. While the challenges cannot be underestimated, ongoing efforts to identify and resolve problems are required not only in health care and education but in other sectors such as housing and infrastructure.

The new government has committed to produce with the states, a White Paper on Reform of the Federation, to be completed by end-2015. The review will attempt to clarify roles and responsibilities, and would appear to lean towards decentralisation. According to government material (Abbott, 2014; Commonwealth Government 2014), the review will focus on making states, as far as possible, "sovereign in their own sphere", with Commonwealth continuing to play the leading role on issues of genuine national interest, but a small role in areas of primary state responsibility including health, education, housing and homelessness.

In tandem with an overhaul in responsibilities, the review will examine, amongst other things, the ways to address the large imbalance between states' own revenue and their spending responsibilities. Increased fiscal autonomy should be combined with increased responsibility. In this context, the intention of the government to consider both the spending, and taxation, roles and responsibilities of the different levels of government (as part of the forthcoming Reform of the Federation White Paper, in conjunction with the related Taxation White Paper) is welcome. The white paper background material also emphasises the need to reduce, and, as far as possible, eliminate, waste and duplication and simplify the interaction between government and citizens (Abbott, 2014; Commonwealth of Australia, 2014).

The comprehensive review of the federal system, along with the "whole-of-government" approach to the process through the involvement of the states, are welcome. International experience points to benefits from clearly defining the roles and responsibilities of the central and sub-central governments. This is the case, for example, in Switzerland where the separation of the majority of federal and cantonal tasks (not yet fully completed) under a recent reform has yielded positive results, such as important savings for the construction of national roads (Bessard, 2013; Clemens and Veldhuis, 2013).

Reforming Australia's federal system appears also to have public support. A recent survey on constitutional values by the Griffith University shows that two-thirds of the respondents see scope for improving the functioning of the federal system, yet with no clear preference as to whether decisionmaking should be at the Commonwealth or state/local level (Brown, 2012b).

Efforts to clarify the roles and responsibilities within shared functions, and to encourage coordination, should continue. For some sectors, however, deeper reform may be required; in particular by re-allocating responsibilities between the federal and state governments. Responsibilities should be allocated on the basis of the "subsidiarity" principle (i.e., responsibility should rest, as far as practical, with the level of government closest to the people receiving those services), while ensuring consistency between national and sub-national policies. 
In education, for example, the National Commission of Audit recommends transferring more policy and funding responsibilities for schools and VET to the states, while retaining national mechanisms for ensuring consistency and quality (NCA, 2014). For instance, for the shorter run, the report makes a case for states managing the funding for both public and private schools, rather than as currently that each school sector has its own approach to allocating funding, as discussed above. Over the longer term, the states could undertake more funding responsibilities for schools, if VFI were reduced, with the Commonwealth retaining a co-ordinating role in areas such as national curriculum (NCA, 2014). The new funding arrangements for schools announced in the May 2014 budget, to commence from 2017-18, appear to go in this direction and are in line with reforms in some federal countries, for example, Switzerland (Bessard, 2013). OECD analysis generally suggests that appropriate decentralisation in school education (encompassing school autonomy and other aspects of education regulation and management, rather than simply sub-central shares of spending) can help to increase education performance (OECD, 2013b).

In healthcare, international comparisons show that many countries have scope for enhancing consistency in the assignment of responsibility between federal and state governments (Figure 10). Australia's relatively low score reflects the overlapping responsibilities in the sector. Countries have moved in different directions on this front. Some (such as Italy and Spain) have in recent years transferred some health care responsibilities to sub-national levels. Others (including Denmark, Norway, and Poland) re-centralised responsibilities, citing concerns about heightened equity problems, potentially insufficient local funding to finance future heath care needs, duplication and inefficiency and other reasons (Saltman, 2008). Decentralisation could make the health care system more responsive to local needs and promote innovation, but it may also result in institutional complexity, weakening control over spending and insufficient exploitation of economies of scale (Joumard et al., 2010). A careful assessment is required.

Figure 10. Consistency in health-care responsibility assignment across levels of government ${ }^{1}$

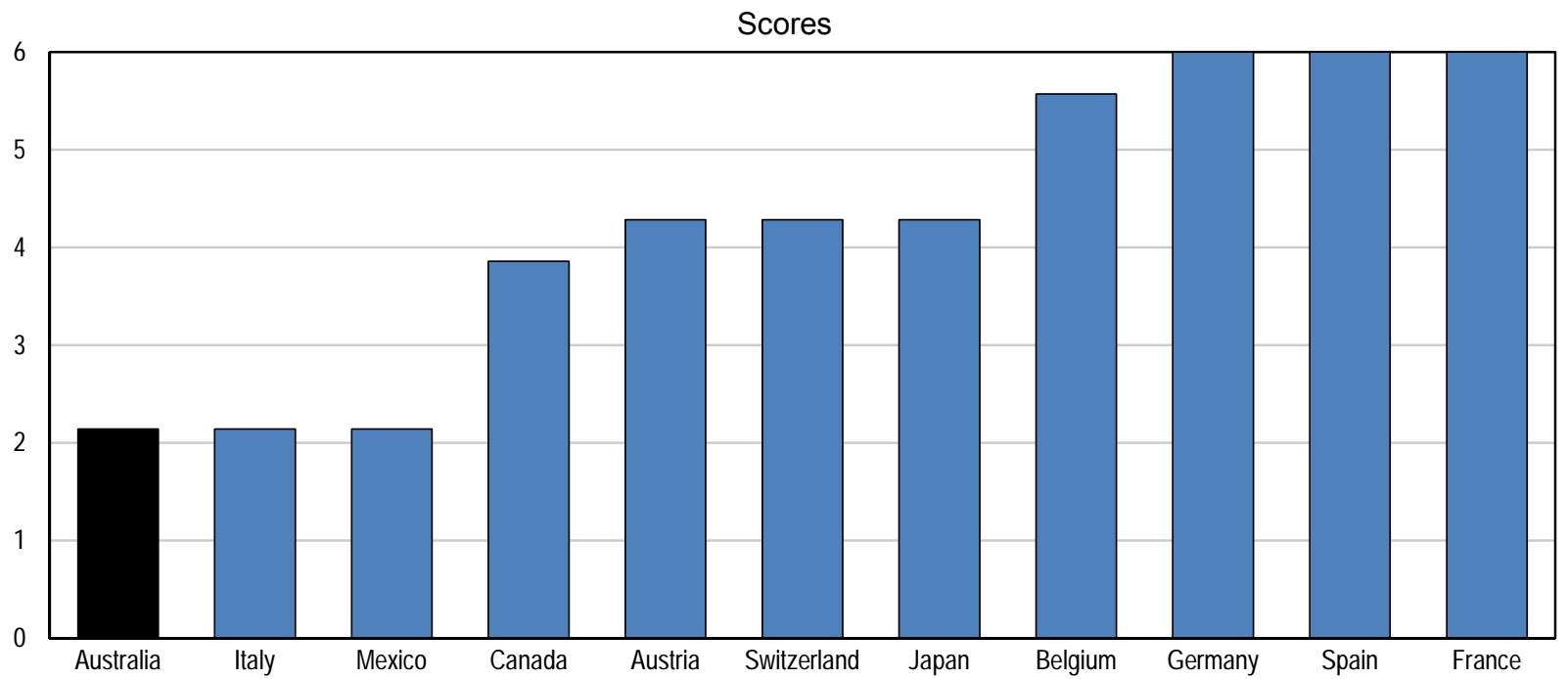

1. The indicator is based on measures of overlapping as well as irrelevance in the decision-making across levels of government. The lower the score, the lower the consistency in responsibility assignment across levels of government.

Source: OECD Survey on Health Systems Characteristics 2008-2009. 


\section{Issues in state-level financing}

\section{Addressing vertical fiscal imbalance}

Vertical fiscal imbalance (VFI) has become an issue in Australia, with concerns that the large fiscal gap potentially reduces accountability and provides opportunities for "blame-shifting" between government levels, reducing the efficiency of public service delivery (Box 4). Much focus has been placed, in this context, on the underlying system of transfers to address the fiscal gap, and whether it gives rise to inefficiencies, with the design of "tied" grants (at least until the recent reforms discussed below) at the centre of the debate. Growing attention has also been given to horizontal fiscal equalisation mechanisms for allocating unconditional federal transfers (GST) among the states (described in Box 2 and discussed further below).

An effective system of inter-governmental transfers that ensures flexibility and accountability is important in dealing with the challenges posed by the vertical fiscal imbalance. But increasing efficiency further, would also require enhancing states' revenue-raising through tax reforms. Recent OECD work concludes, for instance, that tax decentralisation (using Canada as a benchmark) could have a positive impact on Australian growth (OECD, 2013b). While there is no consensus on the ideal degree of decentralisation, sub-central governments should be given sufficient revenue-raising capacity to make them accountable to local citizens (OECD, 2006, 2013c). These issues are discussed below, and become particularly relevant in the context of the current review of the federation and the present government's intention to hand greater responsibilities to the states, making them, as far as practical, "sovereign in their own sphere" (Abbott, 2014; Commonwealth Government, 2014).

\section{Box 4. Vertical fiscal imbalance: Potential consequences for the efficient delivery of services}

A large vertical fiscal imbalance (VFI) is often argued to weaken the link between government taxation and expenditure, reducing the efficiency in the delivery of services. Moreover, as both governments fund public services, a large imbalance reduces accountability to the public and provides incentives for blame-shifting between different government levels (BCA; 2013; NCA, 2014). Critics also claim that the vertical fiscal imbalance increases duplication and overlap in service delivery and the administration burden, through a blurring of roles and responsibilities (Australian Government, 2008; CAF, 2009). The increased scope the imbalance provides for central government in areas of sub-national responsibility, through the conditionality of federal transfers, raises additional concern (Banks, et al., 2012).

Large vertical fiscal gaps may also reduce incentives for fiscal discipline, according to recent cross-country analyses (Eyraud and Lusinyan, 2011, 2013). Some also argue that, a significant imbalance leads to misallocation of resources (including inadequate or inappropriate funding) and slows governments' responsiveness to their communities' needs (CAF, 2009).

However, a large vertical imbalance has some potential benefits. These include, for example, the economies of scale that can be exploited in centralising tax collection; more uniform standards of sub-national government services; increased scope for reforms of national interest; and smoother economic cycles by enabling the central government to influence the allocation of resources in the economy (for further discussion, see OECD, 2006; Australian Government, 2008).

\section{There is scope to reduce further the strings attached to federal grants}

Grant conditionality may be justified on the grounds of ensuring minimum national standards for the provision of public service but there are also counter arguments (Ter-Minassian, 1997). Australia's tied grants have long been criticised for their complexity, administrative costs, and the inflexibility and conditions attached to them (Warren, 2006; Ward, 2009; Ramamurty, 2012). In a welcome move, the 2008 Intergovernmental Agreement on Federal Financial Relations (IGA) (Box 3) consolidated over 90 Specific Purpose Payments into five, largely untied, broad payments (each associated with a National Agreement) covering health, schools, skills and workforce development, disability services and affordable housing 
(Australian Government, 2009a; Banks et al., 2012). The 2008 reform also enhanced service-performance requirements (largely regarding measurement and accountability) as part of an effort towards outcomebased policy; however the reform did not make the provision of funding contingent on such achievements (Australian Government, 2009a; CRC, 2013a).

The intentions of the 2008 Intergovernmental Agreement on Financial Relations (IGA) were commendable. More flexible and transparent state funding arrangements are in line with the general principles of best-practice inter-governmental fiscal arrangements; enhancing states' incentives for innovative policy solutions and efficient service delivery (OECD, 2008, 2013c). Less complexity and conditionality also brings Australia closer to the practice of other federations. Transfer payments in Canada, for example, entail three broad programmes: the Canada Health Transfer, with specified use for health care; Canada Social Transfer, which allows provinces considerable leeway in social programmes; and unconditional equalisation payments (Clemens and Veldhuis, 2013).

The recent reforms did not deliver, however, the expected outcomes (CRC, 2013a; NCA, 2014). There has been excessive resort to National Partnership Payments - a new form of grant under the IGA which are designed to help deliver national reforms and contain conditionality clauses (Box 3). Increased use of such payments partly arose from stimulus measures to counter the consequences of the global financial and economic crisis of 2008 (Fenna and Anderson, 2012; OECD, 2012b). In other countries too, earmarked and matching constituted a significant share of the national "stimulus" packages to cope with the economic downturn (Smart and Bird, 2009). Even though stimulus-related measures have largely been phased down, these National Partnership Agreements remain numerous. As of mid-2013, there were over 140 of such agreements, with the corresponding payments accounting for about a third of all tied grants. This marks a re-assertion of Commonwealth direction over funding. Moreover, the proliferation of these partnerships has reportedly increased the monitoring, administrative and reporting costs for the Commonwealth and states (CRC 2013a; OECD, 2012b), contrasting IGA's key objective for reduced red tape.

Welcome efforts have been made to lighten and rationalise the National Partnership Agreements. A streamlined version ("project agreements") has been operating since early 2011 for lower risk/lower value agreements. Project agreements typically include less detail and reporting requirements than National Partnerships and focus on straightforward service delivery or project outputs (than outcomes). And, the Council of Australian Governments (COAG) agreed at end-2013 to consolidate 31 of the Partnerships into four, with the new arrangements to take effect in 2014.

However, reform could go further by converting some types of National Partnership Payments into less conditional National Specific Purpose Payments. The OECD report Value for Money for Australia (OECD, 2012b) has recommended, in particular, such conversion for Partnerships that are not time limited. This could be the case, for example, with agreements on early education and care, aiming to improve the quality of services and outcomes for all children, especially those from disadvantaged backgrounds. As regards time-limited agreements, the 2008 framework contains a mechanism for these transformations (or general revenue assistance), but this has not yet been used. Reduction in grant conditionality through such mechanisms would enhance further the flexibility and transparency of the transfer system, while making state funding more predictable, which could facilitate and encourage efficient service delivery.

\section{Increasing the efficiency of the state tax base}

Some economically more efficient tax bases, notably land tax, are not fully utilised by sub-national governments. The ratio of property tax revenue to GDP is above the OECD average but lower than in several countries (Figure 11). Exemptions for owner-occupied housing alone are estimated to diminish the state land tax base by around 60\% (Australian Government 2009b). Several other land uses are exempt 
from state-based land tax, including primary production land and land owned and used by non-profit organisations and charities. Moreover, tax free thresholds effectively exempt many small scale investors (OECD, 2006). Aside from foregone revenue, the exemptions distort land-use. The current system, for example, places a particular burden on large property developers that may explain, to an extent, the relative low rental of apartment buildings in Australia (OECD, 2010, 2012a). The exemptions also ramp up compliance and administration costs. The state land-tax base should be broadened to include owneroccupied housing and other exempted assets. There is also scope to increase the utilisation of the rates base by sub-national governments (Figure 6). Municipal rates are applied broadly across all residential land, with few exemptions, and are based usually on the unimproved capital value of land. They are considered to be an efficient tax base (see, for example, Australian Government, 2009b; and Lambert, 2011).

Figure 11. Taxes on immovable property

2012 or latest year, as a percentage of $\mathrm{GDP}^{1}$

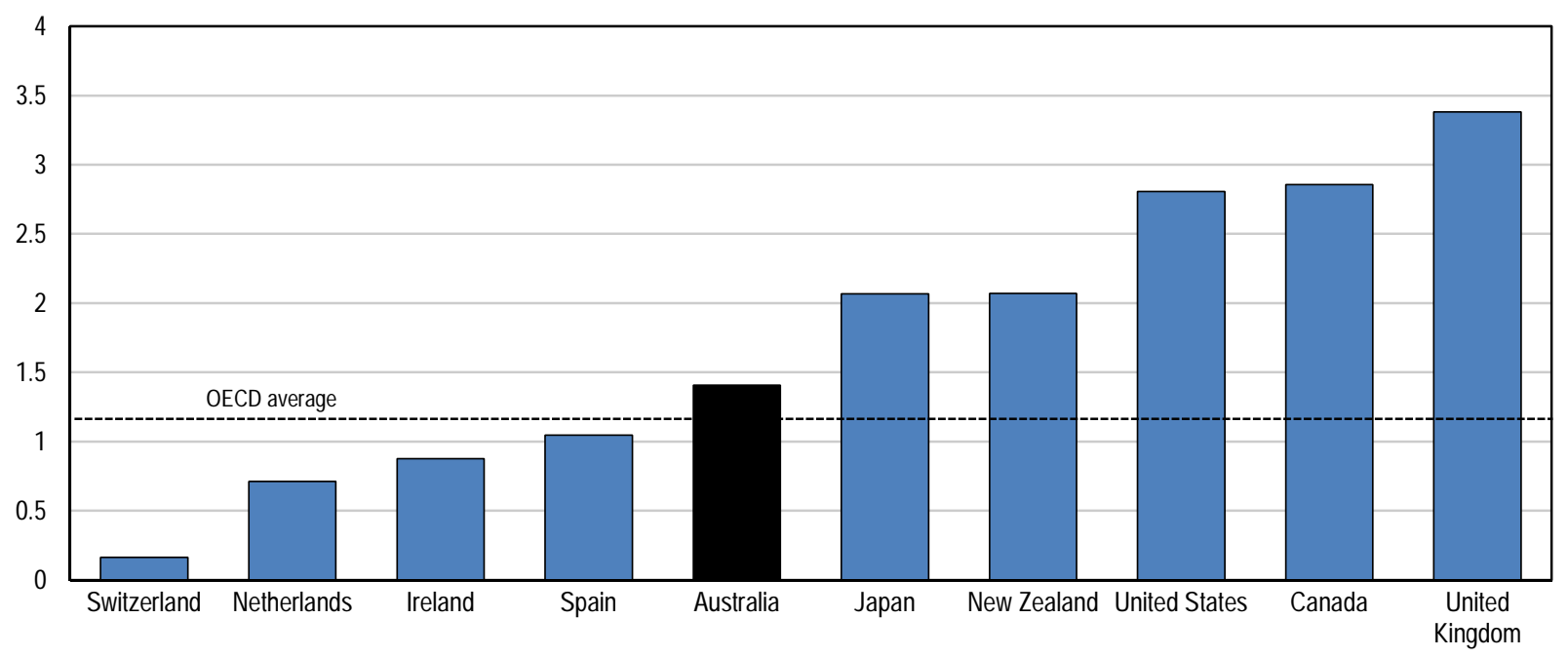

1. 2011 for Australia, Netherlands and OECD. The OECD aggregate is an unweighted average.

Source: OECD (2014), Revenue Statistics.

States impose stamp duties on conveyances of real property (the transfer of property), which can dissuade household mobility and diminish the efficiency of the housing market (Warren, 2006; OECD 2010). Around a fourth of the tax revenue in 2012-13 came from stamp duties (and particularly, on real-estate transfers) (ABS, 2014), which is a largely inefficient and volatile tax base (Australian Government, 2009b).These should be removed as recommended by previous Surveys (OECD, 2006, 2010, 2012a). The Australian Capital Territory is demonstrating that reform is possible, with reforms underway entailing a 20 year transition from transaction taxes (stamp duty on residential conveyance) to general municipal rates (McLaren, 2012). Insurance levies (comprising around 9\% of states' total tax revenue; Figure 5), are also highly distortionary, as pointed out in a previous Survey (OECD, 2010). Such taxes raise the cost of protection against risk, possibly causing low-income households to under-insure.

Large exemptions are also found in payroll taxes. Although they can increase the cost of labour, payroll taxes have advantages in providing a relatively broad and stable base and low administrative costs (OECD, 2006, 2013c; Warren, 2006). However, only 5\% of businesses are liable (Australian Government, 2009b) due to the wide-ranging exemptions, which include small firms and firms in particular activities (such as charitable and other non-profit organisations). In addition, there are payment exemptions, for instance on payments for maternity leave. Again, the exemptions represent foregone 
revenue but also economic distortions, in this case on the allocation of labour. Australia's Future Tax Review (AFTR) concluded that threshold exemptions explain most of the difference between the actual and "theoretical" payroll tax collections (the latter being the amount that would be collected at current rates from its theoretical base, represented by the national account measure of compensation of employees) (Australian Government, 2009b). Therefore, the narrowly-based payroll tax should be broadened mainly by extending it to smaller firms (OECD, 2006). Existing exemptions also increase the complexity and compliance costs for employers, especially those operating in more than one state, as treatment differs, despite steps towards harmonising payroll tax provisions in recent years.

Overall, as previous Surveys have also suggested (OECD, 2010, 2012a), there is room to enhance the efficiency of the existing state tax systems. This could be facilitated by a "deal" between state and federal governments on state taxation. For instance, states might sign up to getting rid of distortionary taxes if more GST revenues can be offered (following an adjustment in its base and/or rates ${ }^{2}$ ). Broadening the states' land and payroll tax bases could also contribute to a shift towards lower vertical imbalance, in addition to increasing efficiency.

\section{Consider introduction of a state-level income tax}

Better utilisation of relatively efficient existing sub-national tax bases should be a priority, but if additional "own-revenue" is warranted to reduce vertical fiscal imbalance as part of a broad reform of the federation, a state-level personal income tax (PIT) could be considered. The reform should also dovetail with the recommendations made in the 2014 OECD Economic Survey of Australia (OECD, 2014) for a shift towards less reliance on direct taxation at the national level. This could imply that the federal government "makes room" by lowering its personal income tax to accommodate both state-level PIT and national tax reform (OECD, 2006; Australian Government, 2009b; NCA, 2014). Various approaches to state-level PIT can be taken, such as a system where states are allowed to set their rate while keeping a unified base throughout the country (a so-called "piggyback" system). This is likely to involve some economic costs, such as the erosion of the base assigned to states due to horizontal competition and efficiency loss, particularly if multiple rates are applied across jurisdictions. Moreover state-level PIT might make future reform of the income tax base more difficult, given the involvement of more government levels in its determination. However, vertical tax competition (i.e. competition of different levels of government for the same tax base) could partly offset the impact of horizontal competition, according to recent OECD analysis (OECD, 2013a). To reduce complexity and potential inefficiencies from different PIT tax rates across states, individual rates could be set within a nationally agreed band. Moreover, piggybacking state-level PIT on national taxation would limit significantly administration costs, since such tax would be centrally administrated and collected (Fedelino and Ter-Minassian, 2010), although there could be increased red-tape and compliance costs around determining the state in which income is earned. Sub-central income taxes features in many advanced economies, but international experience varies. In Canada, for example, most provinces impose their tax rates on the federal income tax base (modified slightly by provincial and credits rebates), which is collected and administrated centrally (except for Québec). Meanwhile, the Nordic countries apply flat, locally set tax rates, imposed on a common tax base and collected centrally (Bird and Smart, 2010). Furthermore, in the United States and Switzerland the federal and state levels set PIT rates and bases separately. Any increased revenue powers must go hand in hand with increased responsibility and accountability such that states have strong incentives for maintaining wide tax bases.

2. See OECD (2014). 


\section{The equalisation scheme}

No other country has a system of "full" equalisation akin to that in Australia (Box 2), where both revenue and expenditure capacity are equalised (Australian Government, 2011; OECD, 2013b) (Table 2). The process in many countries aims to ensure a minimum standard of services, rather than full equalisation (Table 3). The Australian system does not equalise actual levels of service; the goal is to equalise state fiscal capacities to do so, but the actual standard delivered is a matter of policy for each state (Australian Government, 2011).

Table 2. Fiscal disparities before and after equalisation

Gini coefficients and ratio of the wealthiest to the poorest jurisdiction

\begin{tabular}{lrr|rr|rr|rr}
\hline & \multicolumn{4}{c}{ Gini coefficient } & \multicolumn{3}{c}{ Ratio of highest to lowest tax-raising capacity } \\
\cline { 2 - 10 } & \multicolumn{3}{c}{ Before equalisation } & \multicolumn{2}{c|}{ After equalisation } & \multicolumn{2}{c}{ Before equalisation } & \multicolumn{2}{c}{ After equalisation } \\
\cline { 2 - 10 } & 2005 & 2012 & 2005 & 2012 & 2005 & 2012 & 2005 & 2012 \\
\hline Australia & 0.05 & 0.07 & 0.00 & 0.00 & 4.8 & 7.5 & 1.0 & 1.0 \\
Austria & & & 0.02 & 0.05 & & & 1.1 & 1.5 \\
Canada & 0.10 & 0.11 & 0.07 & 0.08 & 2.4 & 2.4 & 1.7 & 1.8 \\
Germany (2005) & 0.06 & 0.06 & 0.02 & 0.02 & 1.7 & 1.7 & 1.2 & 1.1 \\
Italy & 0.21 & 0.19 & 0.10 & 0.04 & 6.1 & 4.5 & 1.3 & 1.3 \\
Spain & 0.15 & 0.13 & 0.04 & 0.05 & 2.1 & 3.0 & 1.4 & 1.4 \\
Switzerland & 0.15 & 0.17 & 0.11 & 0.11 & 3.8 & 4.3 & 2.5 & 2.6 \\
\hline
\end{tabular}

Source: OECD (2014), Fiscal Federalism 2014 : Making Decentralisation Work, Table 5.1.

The equalisation process, and its outcomes have come under criticism in Australia at various times, as discussed in a previous Survey (OECD, 2006), and most recently with the substantial changes in the distribution of GST revenue resulted from mining boom (Australian Government, 2011; Banks et al., 2012). Before the boom, the GST redistribution coefficient for the two main "mining states", Western Australia and Queensland was about 1 (which means they received close to $100 \%$ of their respective per-capita weighted shares of GST). During the boom this coefficient fell, especially in Western Australia, where it was about 0.7 in 2011-12. In contrast, the Northern Territory's coefficient, for example, was in 2011-12 over 5 times its equal per capita share (CGC, 2013).

This larger redistribution prompted the four largest states (Victoria, New South Wales, Western Australia and Queensland), which lost out, or remained broadly neutral, to advocate for a more partial equalisation (Australian Government, 2012b; NCA, 2014). In response, the previous federal government launched the GST Distribution Review (the Review) in 2011, examining possible reform options. Issues of complexity, efficiency, and predictability and stability of equalisation outcomes (GST shares) received particular attention.

Submissions to the Review confirmed concerns about complexity and data adequacy and quality, despite previous simplification of equalisation methodology. Complexity was generally believed to inhibit understanding of the equalisation process, and ultimately its acceptance (Australian Government, 2012b). The Review also flagged instability and unpredictability of GST payouts. Detailed concerns included the disruptive effect from the "upfront" treatment of Commonwealth infrastructure payments to states, which have a large impact on the annual relativities (determining how much revenue of the GST pool each state receives compared to an equal per capita share, see Box 2) of the years when payment are made. However, the Review found little supporting evidence for concerns about efficiency losses due to equalisation arrangements, although Clements and Veldhuis (2013) argue that this conclusion might have been different if the review's terms of reference had not specified that desirability of fiscal equalisation is to be taken as given. 
ECO/WKP(2015)16

Table 3. Fiscal equalisation systems in selected federations

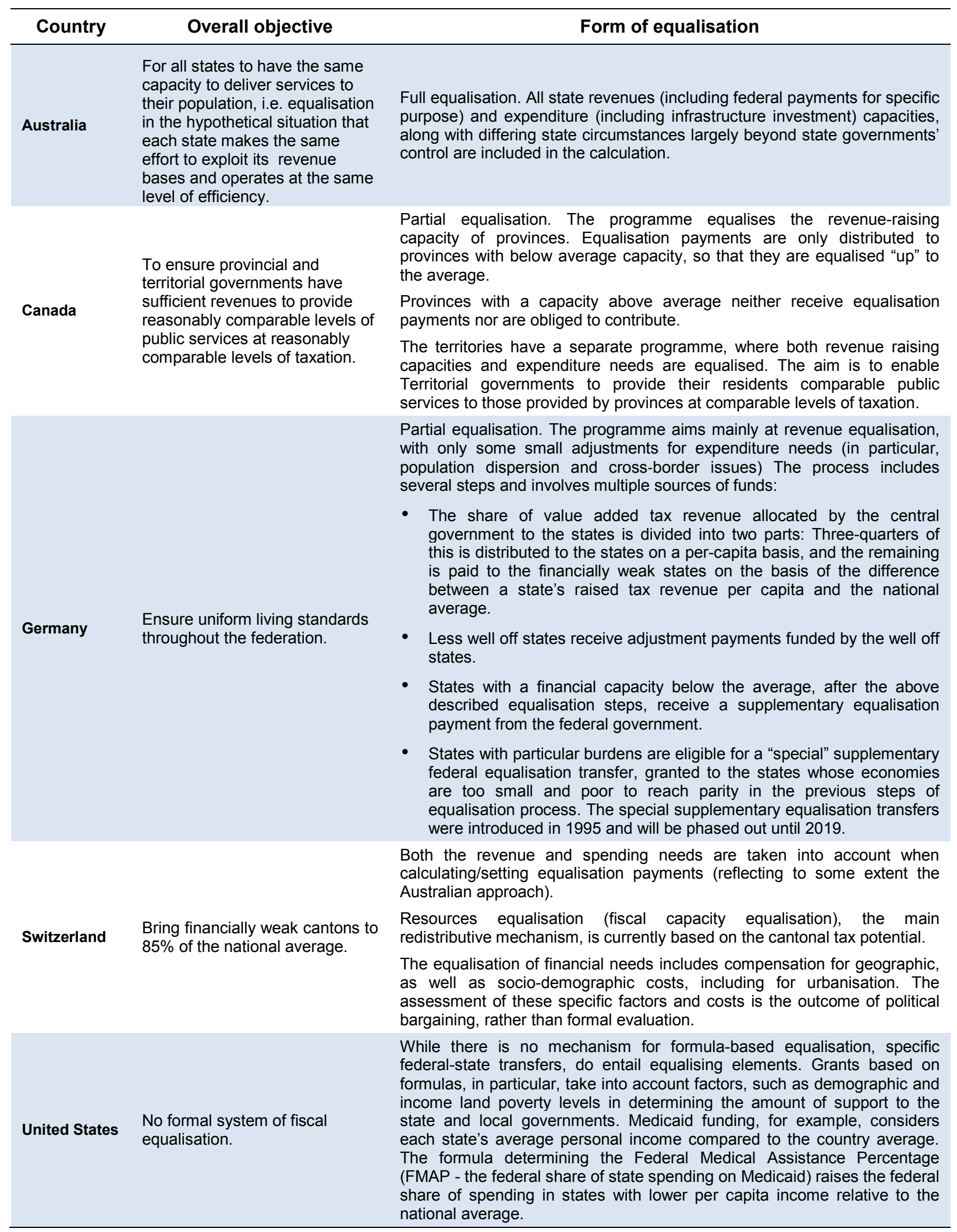

Sources: Warner and Shah (2005); Frey and Wettstein (2008); Australian Government (2012b); Bessard (2013); CBO (2013); Clemens and Veldhuis (2013). 
In its final report (October 2012), the Review did not recommend an overhaul of the equalisation system, arguing that replicating the outcomes of the existing system in a radically simpler way was not feasible (Australian Government, 2012c). However, a range of improvements to enhance governance and stability, and reduce complexity, were suggested. For instance, an increase in "materiality thresholds" (the thresholds set the minimum effect on GST distribution required for a factor to be taken into account in the equalisation process) was proposed to remove the insurance tax and six "cost disabilities" (e.g. first home owners scheme expenses and water subsidies) from the calculations of GST relativities (Box 2). As regards governance, the final report suggested, amongst other things, subjecting equalisation outcomes to regular independent reviews. These proposals go in the right direction.

There may be scope to further simplify the current equalisation system. A wide range of factors are still taken into consideration in the equalisation process, which makes identification and quantification very complex (Clemens and Veldhuis, 2013). Some equalisation factors, for instance, may become redundant. The methodological reviews of the equalisation process conducted by the Commonwealth Grants Commission every 5 years (Box 2) are welcome to this end, with the new review due to be released in 2015. Such exercises could be carried out at a higher frequency. Greater methodological simplicity would not increase only the transparency of the equalisation process, but also its relevance and responsiveness as well as the reliability of its outcomes by reducing the amount of required information. However, this should not come at increased uncertainty of the rules underlying the distribution of GST revenue. Setting priorities for equalisation categories to be re-examined in future methodological reviews, as proposed by the final report, makes sense (Australian Government, 2012c).

Broader reforms to the federation, for instance towards lower vertical imbalances, may allow for more radical changes in the equalisation system. An option suggested by the final report of the Review and other studies (for example, Garnaut and FitzGerland, 2002; NCA, 2014) would be to move towards allocating the GST revenue on an equal-per capita basis, with fiscally weaker states being accommodated through other mechanisms. The present government's views on the equalisation reform are due to be elaborated in the upcoming White Paper on Reforming Federation.

\section{States can borrow freely but there are disciplining mechanisms}

The Australian states can borrow on their own account with no limits imposed by the central government. Financial markets and rating agencies act in this case as important discipline mechanisms. In addition, the Australian Loan Council monitors borrowing by all levels of government (Craig, 1997). The Council seeks to foster transparency and accountability of public sector finances (including through comprehensive data reporting requirements), rather than securing adherence to strict borrowing limits (OECD, 2006; Australian Government, 2014a). The federal and each state government are required to submit, in this context, their net financing requirements (so called, Loan Council Allocations) for the coming year. Jurisdictions may be requested to provide an explanation to the Council if the agreed financing requirement exceeds the tolerance limit. While the Loan Council cannot provide direct sanctions on jurisdictions' borrowing behaviour it can facilitate scrutiny over borrowing, strengthening potentially fiscal discipline (OECD, 2006). 


\section{There is scope to further improve performance reporting}

Effective reporting on policy approaches and outcomes is important for detecting inefficiency and poor service quality, helping states learn from each other, and increasing accountability. Since 1993 an annual Report on Government Services has monitored the effectiveness and efficiency in public service provision, publishing performance information on 16 broad service areas across education, health justice and community services (SCRGSP, 2014). The 2008 Intergovernmental Agreement on Federal Financial Relations (IGA) sought to make additional progress through its focus on "outcomes and outputs" monitoring and improved public reporting by the COAG Reform Council (the Council (Box 3). The Council was tasked to appraise achievement against benchmarks, reporting publicly the results on an annual basis, but ceased operating in June 2014, as part of the government's policy to reduce regulation and red tape.

Despite progress made in some domains, for instance regarding the data for indigenous population and homelessness, performance indicators are of varying quality, and are based on inadequate or outdated data in a number of areas (CRC, 2013a). Moreover, well-developed "outcome" indicators are still absent. Data challenges are partly to blame but some also claim that the proliferation of the prescriptive National Partnership Agreements dissuades indicator development (DAE, 2013). Overall, in its assessment for the period 2008-2012, the Council concluded an "inadequate attention" on the continuous improvement of the performance framework (CRC, 2013a).

Simple and easy-to-quantify audit targets are essential if operational efficiency is to be enhanced (OECD, 2006), but are not easily formulated. The long timeframes usually required for the achievement of outcomes add to challenges of measuring them properly, as it makes it difficult to track progress in practice. Following systematically the effectiveness of reforms in different areas, through the creation of an "evidence base", as recommended by the Council, would be important in this regard, as it would allow monitoring and assessing progress along the way (CRC, 2013a).

In some policy areas reporting requirements are overly burdensome. The National Health Reform Agreement, for instance, includes 22 outcomes, 26 measures, 15 outputs, 70 indicators, and 7 performance benchmarks, generating an unnecessarily heavy reporting and compliance burden (NCA, 2014). A more streamlined performance reporting framework, while ensuring the necessary accountabilities, would bring a welcome reduction in administrative burdens, as highlighted by the National Commission of Audit (NCA, 2014). A review of existing reporting arrangements would be helpful in this regard.

The gap left in performance monitoring and reporting, following the abolition of the COAG Reform Council, needs to be filled through a new or existing entity. The May 2014 budget included some provisions in this regard (giving the Department of the Prime Minister and Cabinet a role to monitor state performance on an ongoing basis). Regarding further options, the NCA's recommendation for the Productivity Commission to perform this role is sensible, in light of the Commission's considerable experience in assessing public services (NCA, 2014). Performance reporting arrangements will be covered in the government's White Paper on Reform of the Federation, with transitional arrangements currently being developed.

As a final note, for performance reporting to be worthwhile it has to have impact. Mechanisms helping service providers learn and adjust in light of performance outcomes are therefore important (Thomas, 2006; CRC, 2013a). A systematic monitoring of the policy impacts of the performance reports is important to this end. Moving in the right direction, the White Paper on federation reform will consider transparency in performance reporting and data arrangements, as well as avenues for making better use of the data to improve outcomes (Commonwealth of Australia, 2014). 


\section{Recommendations for improving federal-state relations}

\section{Address federal-state shared responsibilities to improve efficiency}

- Improve co-ordination and co-operation and, in some cases, health care in particular, consider a reallocation of responsibilities.

- In the school sector, consider giving states the management of funding for all schools. Over the longer term, states could be given greater funding responsibilities combined with increased fiscal powers.

- Clarify the roles and responsibilities of the Commonwealth and the states in the vocational education and training sector (VET), and consider shifting more policy and funding responsibilities to states, while ensuring national consistency and quality.

\section{Reform federal-state financial relations}

- Reduce grant conditionality further, instigate state-level tax reforms to enhance funding autonomy, and increase state-level responsibilities and accountabilities.

- Convert some types of National Partnership Payments into less conditional National Specific Purpose Payments. In particular, roll partnerships with no-time limits, and selected successful time-limited ones, into specific purpose payments.

- Increase the efficiency of existing state-tax mix by abolishing distortionary stamp duties, especially on conveyance of real property, and by increasing the reliance on efficient taxes. The forgone revenue could be met by broadening land-tax base and an increase in revenues from the Goods and Services Tax (GST) transferred to the states.

- Broaden the land-tax base to include owner-occupied housing and other exempted assets.

- Broaden the payroll tax mainly by extending it to smaller firms; further harmonise payroll tax provisions across states.

- Consider a state-level personal income tax as part of a broad reform of the federation, while dovetailing with the recommendations made in the 2014 OECD Economic Survey of Australia for a shift towards less reliance on direct taxation at the national level.

- Consider simplifying further horizontal fiscal equalisation. Increase the frequency of methodological reviews, but monitor closely for unintended effects on uncertainty regarding the rules underlying the distribution of GST revenue. In future methodological reviews, prioritise which equalisation categories will be re-examined.

\section{Strengthen capacity for assessing and comparing state-level public services}

- $\quad$ Further develop performance indicators; and continue enhancing the availability and quality of data. Prioritise demands on data improvements in view of the high costs involved in the process.

- Expedite the development of outcome-based indicators. Simple and easy-to-quantify audit targets are essential to enhance operational efficiency. Create an "evidence base" for the effectiveness of reforms in different areas to allow to monitor and assess progress along the way.

- Prune reporting requirements that are superfluous to acquiring the necessary data for performance evaluation and accountability. Proceed with a review of existing reporting arrangements.

- $\quad$ Fill the gap in performance monitoring and reporting following the abolition of the COAG Reform Council, through a new or existing entity (such as the Productivity Commission). Monitor the policy impacts of the performance reports. 


\section{BIBLIOGRAPHY}

Abbott, T. (2014), "White Paper of Reform on the Federation", Prime Minister of Australia, Media Centre, June.

ABS (Australian Bureau of Statistics) (2012), Health care Delivery and Financing, Year Book Australia

ABS (2014), Taxation Revenue Australia 2012-13, ABS ca. no. 5506.0, May.

ACTEP (Australian Council for Private Education and Training) (2013), "ACTEP Submission to the National Commission of Audit", www.ncoa.gov.au.

Anderson, J., (2012), "Health Policy as Contested Terrain in the Australian Federation", Tomorrow's Federation: Reforming Australian Government, Federation Press, Leichhardt, NSW, pp. 246-268.

Australian Government (2008), Australia's Future Tax System - Architecture of Australia's Tax and Transfer System, Commonwealth of Australia, Canberra.

Australian Government (2009a), Budget Paper No.3: Australia's Federal Relations, 2009-10, Australian Government, Canberra, May.

Australian Government (2009b), Australia's Future Tax System - Report to the Treasurer, Commonwealth of Australia, Canberra.

Australian Government (2010a), A National Health and Hospitals Network for Australia's Future, Commonwealth of Australia, Canberra.

Australian Government (2010b), Budget Paper No.3: Australia's Federal Relations, 2010-11, Australian Government, Canberra, May.

Australian Government (2011), Submission to the GST Distribution Review, The Treasury, October, Canberra.

Australian Government (2012a), Budget Paper No.3: Australia's Federal Relations, 2012-11, Australian Government, Canberra, May.

Australian Government (2012b), GST Distribution Review - Interim Report, Commonwealth of Australia, March., Canberra.

Australian Government (2012c), GST Distribution Review - Final Report, Commonwealth of Australia, October, Canberra.

Australian Government (2013), Budget Paper No.3: Australia's Federal Relations, 2013-14, Australian Government, Canberra, May.

Australian Government (2014a), Budget Paper No.3: Australia's Federal Relations, 2014-15, Australian Government, Canberra, May.

Australian Government (2014b), Budget Overview, 2014-15, Australian Government, Canberra, May. 
Banks, G., A. Fenna , and L. McDonald (2012), “Australia's Federal Context”, Productivity Commission and Forum of Federations 2012- Benchmarking in Federal Systems, Roundtable Proceedings, Melbourne, 19-20 December 2010, eds A. Fenna and F. Knüpling, Productivity Commission, Canberra.

BCA (Business Council of Australia) (2006), Reshaping Australia's Federation: a New Contract for Federal-State Relations, BCA, November.

BCA (2013), Action plan for Enduring Prosperity, July.

Bessard, P., (2013), "Switzerland's Reformed Fiscal Equalisation System - Still Substantial Room for Improvement", in Federalism and Fiscal Transfers: Essays on Australia, Germany, Switzerland and the United States, eds. Clemens J. and N. Veldhuis, Fraser Institute, October.

Bird, R., and M. Smart (2010), “Assigning State Taxes in a Federal Country: The Case of Australia”, in Melbourne Institute - Australia's Future Tax and Transfer Policy Conference : Proceedings of a Conference, Commonwealth of Australia.

Blöchliger, H. and C. Vammalle (2012), Reforming Fiscal Federalism and Local Government: Beyond the Zero-Sum Game, OECD Fiscal Federalism Studies, OECD Publishing, Paris.

DOI: http://dx.doi.org/10.1787/9789264119970-en

Brown A.J, (2012a), "Escaping Purgatory: Public Opinion and the Future of Australia's Federal System", in The Future of Australian Federalism: Comparative and Interdisciplinary Perspectives, edited by G. Appleby, N. Aroney, and T. John, Cambridge University Press, Cambridge, pp. 363-392.

Brown A.J. (2012b), “Australian Constitutional Values Survey 2012”, Griffith University, November.

CAF (Council for the Australian Federation) (2009), “Australia's Future Tax System - State Perspective”, mimeo.

CBO (Congressional Budget Office) (2013), "Federal Grants to States and Local Governments”, Congress of the United States, March.

CEDA (Committee for Economic Development of Australia) (2013), Healthcare: Reform or Ration, CEDA, Melbourne.

CGC (Commonwealth Grants Commission) (2013), Report on GST Revenue Sharing Relativities - 2013 Update, Commonwealth of Australia, Canberra.

Clemens J. and N. Veldhuis (2013), "Executive Summary", in Federalism and Fiscal Transfers: Essays on Australia, Germany, Switzerland and the United States, eds. Clemens J. and N. Veldhuis, Fraser Institute, October.

COAG (Council of Australian Governments) (2010), National Health and Hospitals Network Agreement, COAG.

Commonwealth of Australia (2014), "Reform of the Federation White Paper - A Federation for Our Future: Issues Paper 1”, September.

Craig, J. (1997), "Australia", in Fiscal Federalism in Theory and Practice, edited by T. Ter-Minassian, International Monetary Fund, Washington, pp. 175-200. 
CRC (COAG Reform Council) (2012), Affordable Housing 2010-11: Comparing Performance Across Australia, COAG Reform Council, Sydney.

CRC (2013a), Lessons for Federal Reform: COAG reform Agenda 2008-2013, Report to the Council of Australia, COAG Reform Council, Sydney.

CRC (2013b), Homelessness 2011-12: Comparing Performance Across Australia, National Affordable Housing Agreement- COAG Reform Council, Sydney.

DAE (Deloitte Access Economics) (2013), “Assessment of Progress Under COAG Reform Agenda”, Input for COAG Reform Council, Deloitte, November.

Eyraud, L., and L. Lusinyan (2011), "Decentralizing Spending More than Revenue: Does It Hurt Fiscal Performance?”, IMF Working Paper, WP/1 1/226, IMF, Washington D.C.

Eyraud, L., and L. Lusinyan (2013), "Vertical Fiscal Imbalances and Fiscal Performance in Advanced Economies", Journal of Monetary Economics, Vol. 60, 571-587.

Fedelino, A. and T. Ter-Minassian (2010), "Making Fiscal Decentralisation Work: Cross-Country Experiences", IMF Occassional Paper 271.

Fenna, A. (2007), "The Division of Powers in Australian Federalism: Subsidiarity and the Single Market", Public Policy, vol. 2, no. 3, pp. 175-94.

Fenna, A. (2012a), “The Character of Australian Federalism”, eJournal of Tax Research, vol. 10, no.1, February.

Fenna, A. (2012b), “Adaptation and Reform in Australian Federalism”, in P. Kildea, A. Lynch, and George W. (eds.), Tomorrow's Federation: Reforming Australian Government, Federation Press, Leichhardt, NSW, pp. 26-42.

Fenna, A. and G. Anderson (2012), "The Rudd Reforms and the Future of the Australian Federalism", in The Future of Australian Federalism: Comparative and Interdisciplinary Perspectives, edited by G. Appleby, N. Aroney, and T. John, Cambridge University Press, Cambridge, pp. 393-413.

Frey, R.L. and G. Wettstein, (2008), "Reform of the Swiss Fiscal Equalisation System", CESifo DICE Report, 1.

Garnaut, R. and V. FitzGerald (2002), "Issues in Commonwealth-State Funding”, The Australian Economic Review, Vol. 35, No. 3, Blackwell Publishing.

Joumard, I., C. André and C. Nicq (2010), "Health Care Systems: Efficiency and Institutions", OECD Economics Department Working Papers, No. 769, OECD Publishing, Paris.

DOI: http://dx.doi.org/10.1787/5kmfp51f5f9t-en

Kirchner, S. (2013), "Lessons from the Australian Experience", in Federalism and Fiscal Transfers: Essays on Australia, Germany, Switzerland and the United States, eds. Clemens J. and N. Veldhuis, Fraser Institute, October.

Lambert, M. (2011), NSW Financial Audit 2011, NSW Treasury. 
McLaren, J. (2012), “The Australian Capital Territory Has Adopted Measures to Abolish Stamp Duty and Impose a Land Tax on All Real Property: Will This Approach Be Adopted By Other States in Australia?", Mimeo.

Murray, R. (2012), “A New Federation with a Cities and Regional Approach", The Australian and New Zealand School of Government.

NCA (National Commission of Audit) (2014), Towards Responsible Government: The Report of the National Commission of Audit, Commonwealth of Australia, Canberra, February.

OECD (2006), OECD Economic Surveys: Australia 2006, OECD Publishing, Paris. DOI: http://dx.doi.org/10.1787/eco_surveys-aus-2006-en

OECD (2008), OECD Economic Surveys: Australia 2008, OECD Publishing, Paris. DOI: http://dx.doi.org/10.1787/eco_surveys-aus-2008-en

OECD (2010), OECD Economic Surveys: Australia 2010, OECD Publishing, Paris. DOI: http://dx.doi.org/10.1787/eco_surveys-aus-2010-en

OECD (2012a), OECD Economic Surveys: Australia 2012, OECD Publishing, Paris. DOI: http://dx.doi.org/10.1787/eco_surveys-aus-2012-en

OECD (2012b), Value for Money in Government: Australia 2012, Value for Money in Government, OECD Publishing, Paris.

DOI: http://dx.doi.org/10.1787/9789264178809-en

OECD (2013a), Education Policy Outlook: Australia, OECD Publishing, Paris. DOI: $10.1787 / 9789264225442$-en

OECD (2013b), Fiscal Federalism 2014: Making Decentralisation Work, OECD Publishing, Paris. DOI: http://dx.doi.org/10.1787/9789264204577-en

OECD (2013c), OECD Economic Surveys: Mexico 2013, OECD Publishing, Paris. DOI: http://dx.doi.org/10.1787/eco_surveys-mex-2013-en

OECD (2014), OECD Economic Surveys: Australia 2014, OECD Publishing, Paris. DOI: http://dx.doi.org/10.1787/eco_surveys-aus-2014-en.

O'Meara, P and A. Faithfull (2012), "Increasing Accountability at the Heart of the Federation", in Tomorrow's Federation: Reforming Australian Government, P. Kildea, A. Lynch, and G. Williams (eds.), Federation Press, Leichhardt, NSW, pp. 92-112.

PC (Productivity Commission) (2005), Annual Report, 2004-2005, Productivity Commission, Canberra.

Ramamurty, V., (2012), “Tied Grants and Policy Reform in Public Hospitals and Schools”, in Tomorrow's Federation: Reforming Australian Government, P. Kildea, A. Lynch, and G. Williams (eds.), Federation Press, Leichhardt, NSW, pp. 114-130.

Rimmer, B. (2012), "Benchmarking, Competitive Federalism and Devolution: How the COAG Reform Agenda Will Lead to Better Services", in Productivity Commission and Forum of Federations 2012, Benchmarking in Federal Systems, Roundtable Proceedings, Melbourne, 19-20 December 2010, eds. A. Fenna and F. Knüpling, Productivity Commission, Canberra. 
Saltman, R. (2008), “Decentralization, Re-centralization and Future European Health Policy”, European Journal of Public Health, Vol. 18, No. 2.

SCRGSP (Steering Committee for the Review of Government Service Provision) (2014), Report on Government Services 2014, Productivity Commission, Canberra.

Skills Australia (2011), Skills for Prosperity: A Roadmap for Vocational Education and Training, Commonwealth of Australia, May.

Smart, M. and R., Bird (2009), "Earmarked Grants and Accountability in Government", University of Toronto, October, Mimeo.

Ter-Minassian, T. (1997), "Intergovernmental Fiscal Relations in a Macroeconomic Perspective: An Overview", in Fiscal Federalism in Theory and Practice, edited by T. Ter-Minassian, International Monetary Fund, Washington, pp. 3-24.

Thomas, P., (2006), Performance Measurement, Reporting, Obstacles and Accountability - Recent Trends and Future Directions, Department of Political Studies, University of Manitoba. Retrieved 19 September 2013 from the Australian Competition and Consumer Commission.

Twomey, A. and G. Withers (2007), Federalist Paper I-Australia's Federal Future, A Report for the Council for the Australian Federation, April.

Ward, G. (2009), "New Generation Specific Purpose Payments, Sweeping Reform Across Government", Queensland Government Treasury, Brisbane.

Warner, J. and A., Shah (2005), "Fiscal Equalisation in Germany”, World Bank-info worldbank.

Warren, N. (2006), "Benchmarking Australia's Intergovernmental Fiscal Arrangements", Interim Report, New South Wales Treasury, Sydney. 
ECO/WKP(2015)16

\section{WORKING PAPERS}

The full series of Economics Department Working Papers can be consulted at www.oecd.org/eco/workingpapers

1197. Sharing the fruits of growth in Mexico

(April 2015) by Eduardo Olaberriá and Valéry Dugain

1196. What makes Mexican's happy?

(April 2015) by Valéry Dugain and Eduardo Olaberriá

1195. Improving the labour market integration of immigrants in Belgium

(March 2015) by Álvaro Pina, Vincent Corluy and Gerlinde Verbist

1194. Raising the potential of the domestically oriented sector in Germany

(March 2015) by André Eid and Andrés Hutfilter

1193. Improving transport infrastructure in Russia

(March 2015) by Alexander Kolik, Artur Radziwill and N atalia Turdyeva

1192. Improving the business climate in Russia

(March 2015) by Arthur Radziwill and Yana Vaziakova

1191. Determinants of female entrepreneurship in India

(March 2015) by Arnaud Daymard

1190. The changing role of the exchange rate for macroeconomic adjustment

(March 2015) by Patrice Ollivaud, Elena Rusticelli and Cyrille Schwellnus

1189. Boosting productivity in Russia: skills, education and innovation

(March 2015) by Lilas Demmou and Andreas Wörgötter

1188. Boosting growth and reducing informality in Mexico

(March 2015) by Sean Dougherty

1187. The conduct of monetary policy in the future: instrument use

(March 2015) by Kei-Ichiro Inaba, Rory O'Farrell, Łukasz Rawdanowicz and Ane Kathrine Christensen

1186. A constant market share analysis of Spanish goods

(February 2015) by Alberto Gonzalez Pandiella

1185. Raising the economic participation of women in India - a new growth engine?

(February 2015) by Piritta Sorsa

1184. Improving health outcomes and health care in India

(January 2015) by Isabelle Joumard and Ankit Kumar

1183. Challenges and opportunities of India's manufacturing sector

(January 2015) by Isabelle Joumard, Urban Sila and Hermes Morgavi

1182. The heterogeneity of product market regulations 
(December 2014) by Jean-Marc Fournier

1181. Implicit regulatory barriers in the EU single market: new empirical evidence from gravity models

(December 2014) by Jean-Marc Fournier, Aurore Domps, Yaëlle Gorin, Xavier Guillet and Délia Morchoisne

1180. Can pro-growth policies lift all boats? An analysis based on household disposable income (December 2014) by Orsetta Causa, Alain de Serres and Nicolas Ruiz

1179. Empirical evidence on the effects of environmental policy stringency on productivity growth (December 2014) by Silvia Albrizio, Tomasz Koźluk and Vera Zipperer

1178. The Indicators of the Economic Burdens of Environmental Policy Design - Results from the OECD Questionnaire

(December 2014) by Tomasz Koźluk

1177. Measuring Environmental Policy Stringency in OECD Countries-A Composite Index Approach (December 2014) by Enrico Botta and Tomasz Koźluk

1176. Do Environmental Policies Matter for Productivity Growth? Insights from new Cross-Country Measures of Environmental Policies

(December 2014) by Silvia Albrizio, Enrico Botta, Tomasz Koźluk and Vera Zipperer

1175. Making economic growth more socially inclusive

(December 2014) by Andrés Fuentes Hutfilter and Andreas Kappeler

1174. New tax and expenditure elasticity estimates for EU budget surveillance

(December 2014) by Robert W.R. Price, Thai-Thanh Dang and Yvan Guillemette

1173. Moving towards a more dynamic business sector in Spain

(November 2014) by Alberto Gonzalez Pandiella

1172. Better harnessing talent and knowledge to boost sustainable medium-growth in Spain (November 2014) by David Haugh and Ben Westmore

1171. The internet economy - regulatory challenges and practices

(November 2014) by Isabell Koske, Rosamaria Bitetti, Isabelle Wanner and Ewan Sutherland

1170. A revival of the private rental sector of the housing market? Lessons from Germany, Finland, the Czech Republic and the Netherlands

(October 2014) by Rik de Boer and Rosamaria Bitetti

1169. Secular stagnation: evidence and implications for economic policy

(October 2014) by Łukasz Rawdanowicz, Romain Bouis, Kei-Ichiro Inaba and Ane Kathrine Christensen

1168. Investment gaps after the crisis

(October 2014) by Christine Lewis, Nigel Pain, Jan Strasky and Fusako Menkyna 